\title{
Oligomers, fact or artefact? SDS-PAGE induces dimerization of $\beta$-amyloid in human brain samples
}

Andrew D. Watt, ${ }^{a b c}$ Keyla A. Perez, ${ }^{a b c}$ Alan Rembach, ${ }^{c}$ Nicki A. Sherrat, ${ }^{b}$ Lin Wai Hung, ${ }^{a b}$ Timothy Johanssen, ${ }^{\mathrm{abc}}$ Catriona A. McLean, ${ }^{\mathrm{e}}$ Woan Mei Kok, ${ }^{\mathrm{bf}}$ Craig A. Hutton, ${ }^{\mathrm{b} f}$ Michelle FoderoTavoletti, ${ }^{\mathrm{bc}}$ Colin L. Masters, ${ }^{\mathrm{c}}$ Victor. L. Villemagne, ${ }^{\mathrm{cg}}$ and Kevin J. Barnham ${ }^{\mathrm{abcd} \mathrm{d}^{*}}$

a Mental Health Research Institute, The University of Melbourne, Parkville, Melbourne, Victoria 3052, Australia, ${ }^{b}$ Neuroproteomics Platform, Bio21 Molecular Science and Biotechnology Institute, ${ }^{c}$ Department of Pathology, The University of Melbourne, Parkville, Melbourne, Victoria 3010, Australia, ${ }^{\mathrm{d}}$ Department of Pharmacology, The University of Melbourne, Parkville, Melbourne, Victoria 3052, Australia, ${ }^{\mathrm{e}}$ Department of Anatomical Pathology, The Alfred Hospital, Victoria, 3084, Australia, ${ }^{\mathrm{f}}$ Department of Chemistry, The University of Melbourne, Parkville, Melbourne, Victoria 3052, Australia and ${ }^{\mathrm{g}}$ Department of Nuclear Medicine and Centre for PET, Austin Health, Heidelberg, Victoria 3084, Australia

* Corresponding Author: Kevin Barnham

MHRI and Department of Pharmacology; The University of Melbourne

Victoria, 3010 Australia

Phone: +61-3-83442555

Fax: +61-3-93476750

\section{kbarnham@unimelb.edu.au}




\section{Abstract}

The formation of low-order oligomers of $\beta$-amyloid $(\mathrm{A} \beta)$ within the brain is widely believed to be a central component of Alzheimer's disease (AD) pathogenesis. However despite advances in high-throughput and high-resolution techniques such as xMAP and mass spectrometry (MS), investigations into these oligomeric species have remained reliant on low-resolution Western blots and Enzyme-Linked Immunosorbent Assays (ELISA). The current investigation compared $\mathrm{A} \beta$ profiles within human cortical tissue using sodium dodecyl sulphate (SDS) polyacrylamide gel electrophoresis (PAGE), xMAP and Surface Enhanced Laser Desorption / Ionisation Time-of-Flight (SELDI-TOF) MS and found that whilst there was significant correlation across the techniques regarding levels of monomeric $\mathrm{A} \beta$, only SDS-PAGE was capable of detecting dimeric isoforms of $\mathrm{A} \beta$. The addition of synthetic di-tyrosine cross-linked $A \beta_{1-40} \mathrm{Met}_{35}(\mathrm{O})$ to the $\mathrm{AD}$ tissue demonstrated that the MS methodology was capable of observing dimeric $A \beta$ at femto-molar concentrations, with no noticeable effect on monomeric $A \beta$ levels. Focus turned to the association between SDSPAGE and levels of observable dimeric $\mathrm{A} \beta$ within the AD brain tissue. These investigations revealed that increased levels of dimeric $A \beta$ were observed with increasing concentrations of SDS in the sample buffer. This finding was subsequently confirmed using synthetic $A \beta_{1-42}$ and suggests that SDS was inducing the formation of dimeric A $\beta$. The findings that SDS promotes $\mathrm{A} \beta$ dimerization have significant implications for the putative role of low-order oligomers in $\mathrm{AD}$ pathogenesis and draw into question the utility of oligomeric $\mathrm{A} \beta$ as a therapeutic target.

Keywords: Mass spectrometry, Amyloid, Alzheimer's disease, Western blot, Dimers, Oligomers 


\section{Introduction}

The formation of $\beta$-amyloid (A $\beta$ ) oligomers in the brain and the subsequent progressive deposition of $\mathrm{A} \beta$ are believed to play central roles in Alzheimer's disease (AD) pathogenesis [12]. Initial investigations proposed that fibrillar $A \beta$ was responsible for mediating neurotoxicity however it has long been recognized that fibrillar plaque density and number do not correlate with clinical severity [45,9]. This finding, supported by recent imaging studies $[37,27]$, has led researchers to look elsewhere. More recent investigations have indicated that a strong correlation exists between cognitive impairment and soluble $A \beta$ isoforms [26]. Further attempts to characterize these oligomers, primarily relying on Western blot methods have implicated SDS stable, low-order, oligomeric $A \beta$ as the form of $A \beta$ most likely to cause neuronal dysfunction $[36,52,26,55]$. Not surprisingly the inhibition of $A \beta$ and its oligomers have become attractive targets for therapeutic interventions [52], albeit with limited success [38]. Most recently, the humanized monoclonal antibodies Bapineuzumab, directed at residues 1-5 of the $A \beta$ peptide, and Solanezumab, directed at residues 16-24 of the A $\beta$ peptide, both failed to meet their primary measures of cognition and daily living [15]. These disappointing results have led to speculation within the field of whether targeting $A \beta$ 's accumulation and aggregation remains a legitimate therapeutic strategy.

Initial support for the role of SDS-stable, low-order oligomers stemmed from investigations using Chinese hamster ovary $(\mathrm{CHO})$ cells expressing mutant $(\mathrm{V} 717 \mathrm{~F})$ amyloid precursor protein (APP), known as 7PA2 cells. In addition to monomeric A $\beta, 7$ PA2 cells have been reported to naturally secrete SDS-stable, low-order $A \beta$ oligomers which inhibit synaptic function and disrupt long-term potentiation (LTP), a correlate of memory formation $[51,53,16,54,32]$. Similar disruptions to synaptic function and LTP have recently been 
reported using low-order oligomeric $\mathrm{A} \beta$ isolated from $\mathrm{AD}$-affected human cortical tissue [39].

Given the increasing focus on low-order oligomeric $A \beta$ over the past years we have sought to develop techniques capable of analysing these species using both synthetic $A \beta$ and biological tissues. The use of SELDI-TOF MS, in conjunction with hydrophobic arrays, enabled the resolution of synthetic $A \beta_{1-42}$ species ranging from monomeric to tetrameric bound to lipid rafts [13]. Furthermore, the use of $A \beta$ specific antibodies in conjunction with SELDI-TOF MS enabled the observation of trimeric $A \beta$ in the brains of transgenic mouse models of $A D$ [7] and the observation of dimeric $\mathrm{A} \beta$ in the blood cellular fraction of $\mathrm{AD}$-affected patients [50].

To date despite the ability of high resolution MS techniques to analyse low-order oligomeric $\mathrm{A} \beta$ species, investigations into $\mathrm{AD}$-affected cortical tissue has remained reliant on the lower resolution western blotting techniques. The current investigation aimed to assess whether the ability to observe low-order A $\beta$ oligomers using SELDI-TOF MS was transferable to ADaffected human cortical tissue. The investigation also aimed to evaluate whether the high throughput xMAP multiplex immunoassay could be adapted to measure soluble levels of $A \beta$ in AD-affected cortical tissue. xMAP uses bead-based antibody capture compared to ELISAs microplate wells which result in smaller sample volume requirements and a reduction in nonspecific binding [5]. xMAP is fast becoming a widely used technique in the analysis of A $\beta$ levels in plasma $[20,48,10]$ and cerebrospinal fluid [30,40]. 


\section{Materials and Methods}

\section{Collection and characterisation of brain tissue}

Human brain tissue was collected at autopsy. The sourcing and preparation of the tissue was conducted by the Australian Brain Bank Network (ABBN). Pathological diagnosis of AD was made in accordance with the standard criteria set out by the National Institute on Aging, and Reagan Institute Working Group on Diagnostic Criteria for the Neuropathological Assessment of Alzheimer's Disease [6,28] and pathological diagnosis of frontotemporal lobar degeneration (FTLD) was made in accordance with the guidelines established by the Work Group on Frontotemporal Dementia and Pick's Disease [25,21]. All procedures described in this manuscript were conducted in accordance with the Florey Neurosciences Ethics Committee.

\section{Preparation of human brain homogenate}

Grey matter was isolated from the post-mortem frontal cortices of neurologically normal, FTLD, familial AD (fAD) and sporadic AD affected individuals. The isolated tissue was subsequently added to 1 x Dulbecco phosphate buffered saline (PBS), devoid of $\mathrm{Mg}$ and $\mathrm{Ca}$, (Invitrogen) but containing ethylenediaminetetraacetic acid (EDTA) free protease inhibitors (Roche) to yield $100 \mathrm{mg}$ tissue per $\mathrm{mL}$ of buffer. The brain sample was then homogenized, using an ultrasonic cell disrupter (Virsonic 600; VirTis, Gardiner, NY), three times for 30 seconds each at 24,000 rpm. The protein concentrations of the samples were assessed using the Bradford Assay (BioRad) before the homogenates were aliquoted and stored at $-80{ }^{\circ} \mathrm{C}$ until required. All sample preparation was undertaken on ice. 


\section{Western blot analysis of brain tissue}

Brain homogenates were diluted in SDS-loading buffer, reduced in $10 \% \beta$-mercaptoethanol and heated at $90{ }^{\circ} \mathrm{C}$ for 5 minutes. Protein samples were then separated by $4-10 \%$ SDSPAGE (Invitrogen) and transferred onto nitrocellulose membranes. Nonspecific immunoreactivity was controlled for by blocking the membranes with $5 \%$ non-fat skim milk diluted in tris-buffered saline (TBS) before the membranes were probed overnight with the WO2 antibody [1:500], or for synaptophysin (1:75,000: Millipore). WO2 binds to the Nterminus of $A \beta$ at residues 5-8 [14] and was obtained from the WEHI Monoclonal Antibody Facility. Subsequent to the incubation membranes underwent three 10 minute washes with $0.1 \% \mathrm{TBS} / \mathrm{Tween}$ before the immunocomplex was probed with horseradish peroxidise (HRP) conjugated secondary antibodies.

Probed membranes were washed three times in $0.1 \% \mathrm{TBS} / \mathrm{Tween}$ for $10 \mathrm{~min}$ each, and the immunoreactive proteins were detected using enhanced chemiluminescence upon reaction with ECL (Millipore). Relative optical density of the blots was undertaken using Image J $(1.44 p)$ and western blot densitometry data were normalized to the loading control, $\beta$-tubulin.

\section{SELDI-TOF MS analysis of brain tissue}

Mass spectrometric analysis of the brain tissue was carried out using ProteinChip® PS10 Arrays (Bio-Rad; CAT \#C55-30044) loaded with the specific antibody, WO2 (2 $\mu \mathrm{L}$ at 0.25 $\mathrm{mg} / \mathrm{mL})$ or $\mathrm{G} 2-10(2 \mu \mathrm{L}$ at $0.25 \mathrm{mg} / \mathrm{mL}) . \mathrm{G} 2-10$ binds to the C-terminus of $\mathrm{A} \beta_{40}$ at residues 33-40 [14] and was made in-house. Chips were then incubated overnight at $4{ }^{\circ} \mathrm{C}$ in a humidity chamber before excess antibodies were removed and $10 \mu \mathrm{L}$ blocking buffer $(0.5 \mathrm{M}$ ethanolamine in PBS) was added and incubated for 30 minutes. After the removal of the 
blocking buffer, arrays were washed three times for five minutes with $120 \mu \mathrm{L}$ of $0.5 \%$ Triton X-100/PBS (wash-buffer) followed by three five minute washes with $100 \mu \mathrm{L}$ PBS.

Brain homogenates $(40 \mu \mathrm{L})$ were prepared with $40 \mu \mathrm{L}$ of urea $8 \mathrm{M}$ and $240 \mu \mathrm{L}$ of washbuffer and placed for 10 minutes in an ultra-sound bath with ice. One hundred and fifty microlitres of sample mix was added to each spot and incubated at room temperature for three hours.

Subsequent to incubation, samples were removed and the arrays underwent three 10 second washes on a vigorous shaking table with $150 \mu \mathrm{L}$ wash-buffer, and $150 \mu \mathrm{L}$ PBS, followed by two washes with $150 \mu \mathrm{L}$ HEPES. The arrays were then dried before two $1 \mu \mathrm{L}$ aliquots of a $50 \%$ saturated solution of sinapinic acid (SPA) energy absorbing molecules (EAM) were applied, with air-drying between treatments. The 50\% saturated solution was prepared by suspending $5 \mathrm{mg}$ ProteinChip SPA EAM (Bio-Rad; CAT \# C30-00002) in 0.5\% trifluoroacetic acid (TFA; Sigma-Aldrich; St Louis, Missouri), 50\% acetonitrile (ACN; High performance liquid chromatography (HPLC) grade) and 15\% isopropyl alcohol (IPA; HPLC grade) and $34.5 \%$ HPLC grade $\mathrm{H}_{2} \mathrm{O}$.

Each sample was analysed in duplicate. All arrays were analysed blind to diagnostic status using a ProteinChip SELDI System Enterprise Edition (BioRad). All spectra were internally normalized and peak intensities were normalized using total ion current. Peak detection was carried out using the inbuilt BioRad ProteinChip Data Manager Biomarker Wizard (Version 3.07.004). Peaks were auto-detected to clusters with both first pass signal to noise ratio and valley depth set at 5.0, and a minimum peak threshold of $20 \%$ of all spectra. Cluster completion was achieved with a Cluster Window Mass of 1.0 peak width and a second pass signal to noise ratio and valley depth of 2.0. A $\beta$ species, including potential oxidations, were matched to peaks within the resulting spectra using $\mathrm{m} / \mathrm{z}$. 


\section{INNO-BIA XMAP analysis of brain tissue}

The INNO-BIA plasma $A \beta$ forms assays (Innogenetics NV, Ghent, Belgium), a multiplex microsphere-based Luminex xMAP approach, were adapted to analyse A $\beta$ levels in the PBSsoluble fraction of the brain homogenate, prepared by centrifuging the sample for 30 minutes at $15,000 \mathrm{x}$ g at $4{ }^{\circ} \mathrm{C} . \mathrm{A} \beta_{1-40}, \mathrm{~A} \beta_{1-42}$ and $\mathrm{A} \beta_{\mathrm{n}-40}, \mathrm{~A} \beta_{\mathrm{n}-42}$ were measured using Module $\mathrm{A}$ and $\mathrm{B}$ of the immunoassay kit, respectively.

Assay day 1: All kit components and samples were brought to room temperature (temperature-range $23-25^{\circ} \mathrm{C}$ ) on a laboratory bench. Samples (1 mg tissue / $4 \mathrm{~mL}$ buffer) were centrifuged at $1,500 \mathrm{x}$ g for 5 minutes at room temperature to pellet any precipitates. The samples were then immediately diluted 1:3 in the kit diluent and left at room temperature for an average of 30 minutes while the plate and working solutions were prepared. The beads were vortexed and then incubated for 10 minutes in a sonicating water bath at room temperature. A mixture of a 1:100 bead stock solution was distributed to 96-well filter plates provided in the kit (Millipore Corporation, Bedford, Massachusetts), using calibrated manual multichannel pipettes. The wells were drained by vacuum manifold (Millipore Corporation, Bedford, Massachusetts). Then $75 \mu \mathrm{L}$ of standards, blanks and samples were added to the wells in duplicate, followed by the addition of biotinylated detector MAb ( $25 \mu \mathrm{L} /$ well) (MAb 3D6 for Module A and MAb 2G3 for Module B) and incubated overnight at $2-8{ }^{\circ} \mathrm{C}$ in the dark (plates covered with aluminium foil) on a plate shaker (600 rpm). In addition, on each

plate a two run validation control samples consisting of synthetic $A \beta_{1-40}, A \beta_{1-42}$ were also included.

Assay day 2: The plates were allowed to come back to room temperature on an orbital shaker, covered in foil and were then washed 3 times with diluted wash buffer provided in the kit. After the last wash step, the detection reagent comprising diluted phycoerythrine-labeled streptavidine was added (100 $\mathrm{L} /$ well) and incubated for one hour on an orbital shaker at 
room temperature, covered in foil. The plates were then washed 3x times with wash buffer and $100 \mu \mathrm{L}$ of reading solution, provided in the kit, was added to each well and incubated for 10 minutes at room temperature on an orbital shaker and then analysed. All assays were analyzed on a Bio-Rad Bioplex 200 instrument using v5 software (Bio-Rad Laboratories, USA) with 5PL regression type logistic. The data was fitted to a calibration curve constructed with the median fluorescence values for each replicate of the standards and concentrations were determined by sigmoidal curve fitting. The same batch number was used for all kits assayed in the study and the same algorithm was used for the four analytes.

\section{Preparation of monomeric $A \beta_{1-42}$ and $A \beta_{1-40} \operatorname{Met}_{35}(O)$ dimer}

Synthetic $A \beta_{1-42}$ was purchased from W. M. Keck Laboratory (Yale University, New Haven, CT). Continuous-flow Fmoc-SPPS (solid-phase peptide synthesis) was used for the synthesis of $A \beta_{1-40}$ peptides. Peptides were synthesized on a 0.1 mmol scale using Fmoc-L-Ala-PEGPS resin as a solid support on an Applied Biosystems Pioneer Synthesizer as described previously [47]. A $\beta$ peptides were dissolved in HFIP at a concentration of $1 \mathrm{mg} / \mathrm{ml}(\mathrm{w} / \mathrm{v})$ to induce a monomeric and helical conformation of the peptides [43]. Aliquots of $100 \mu \mathrm{L}$ were dried under vacuum. Dried samples were stored at $-80{ }^{\circ} \mathrm{C}$.

Resin-bound $\mathrm{A} \beta_{11-42} \operatorname{Met}_{35}(O)$ was prepared according to standard methods [1,47]. Dityrosine was prepared according to the previously reported method [2,42]. Fmoc protection of dityrosine and incorporation into SPPS of the $\mathrm{A} \beta_{1-40} \operatorname{Met}_{35}(O)$ dimer was performed according to the previously reported method [18].

Peptide stock solutions were prepared by making a $250 \mu \mathrm{M}$ concentration by weight, dissolving the peptide in $20 \mathrm{mM} \mathrm{NaOH}$, and then diluting in $1 \mathrm{x}$ PBS (1:5). Solutions were 
sonicated in an ice-water bath for five minutes and spun for five minutes at $15800 \mathrm{x} \mathrm{g}$ at $4{ }^{\circ} \mathrm{C}$. The supernatant was retained. The resulting $A \beta$ concentration was determined by using a molar extinction coefficient value of $75,887 \mathrm{~L} / \mathrm{mol} / \mathrm{cm}$ and measuring absorbance at $214 \mathrm{~nm}$ before adjusting the final concentration of the stock solution to $200 \mu \mathrm{M}$. The $\mathrm{A} \beta$ stock solution was subsequently diluted with the stock $20 \mathrm{mM} \mathrm{NaOH}$ in 1 x PBS solution to a concentration of $2 \mu \mathrm{M}$ for analysis using western blots. Synthetic A $\beta$ analysed by SELDITOF MS was prepared in the aforementioned urea / wash buffer solution. All chemicals in the preparation were purchased from Sigma unless otherwise stated.

\section{Statistical Analysis}

Comparisons across the groups for $A \beta$ levels and demographic data were conducted using chi-square tests and one-way Analysis of Variance (ANOVA) with post hoc Tukey's Multiple Comparisons Tests. Bivariate pairwise comparisons were undertaken using Pearson's correlation. Data are presented as mean \pm standard deviation (SD) unless otherwise stated. All analyses were performed using Graphpad Prism® for Windows (Version 5.03, 2009). Outliers deemed significant by the Extreme Studentized Deviate method (ESD) were removed. Statistical comparisons, other than correlations, did not include data from the fAD tissue.

\section{Results}

\section{Subject characteristics}

Clinical information pertaining to the 26 individuals from whom brain tissue was collected is outlined in Table 1. Comparative analysis across the groups revealed a significant difference regarding age at death $(\mathrm{p}=0.0206)$ with post-hoc analyses revealing that the fAD group were significantly younger than the AD group at time of death. Despite trends towards lower total 
brain weight in diseased tissue compared to control tissue no significant differences were observed. Significant differences were not observed across the group for gender ratios and PMI. Evidence of Congophilic Amyloid Angiopathy (CAA) was evident in four of the AD cases, in addition to two of the fAD cases.

\section{Western blot analysis of $A \beta$ in human brain homogenate}

WO2 western blot analysis of the frontal brain homogenate demonstrated that bands consistent with putative 'monomeric' and 'dimeric' A $\beta$ species were clearly visible within all AD brain homogenates in addition to a small proportion of control cortical tissue (Fig. 1a), consistent with previously published reports [33]. Densitometric analysis of the blots revealed that significant differences were evident across the diagnostic groups regarding levels of both 'monomeric' ( $\mathrm{p}=0.0026)$ and 'dimeric' $\mathrm{A} \beta(\mathrm{p}=0.0161)$ with post-hoc analyses revealing that elevated levels of both bands were observed in the AD tissue compared to both control and FTLD tissue (Fig. 1b \& c).

The association between the 'monomeric' and 'dimeric' bands was assessed and revealed a significant positive correlation between the 'monomeric' and 'dimeric' $\mathrm{A} \beta$ bands $(\mathrm{r}=0.696$, $\mathrm{p}=0.0001$ ) (Fig. 1d). Data pertaining to the $\Delta \mathrm{E} 9 \mathrm{fAD}$ case, which showed high levels of both monomeric and dimeric $A \beta$, was shown to be an outlier and was removed from this analysis so as not to drive the positive correlation.

\section{$x M A P$ analysis of $A \beta$ in human brain homogenate}

The adaptation of the xMAP INNO-BIA plasma $\mathrm{A} \beta$ forms assays in the current investigation enabled analysis of the following A $\beta$ isoforms within the PBS-soluble fraction of the brain homogenates: $A \beta_{1-40}, A \beta_{1-42}$ and $A \beta_{n-40}, A \beta_{n-42}$ (Table 2). 
Comparative analysis of $A \beta$ levels showed that significant differences across the groups were evident for levels of $A \beta_{n-40}(p=0.0443), A \beta_{1-42}(p<0.0001)$, and $A \beta_{n-42}(p=0.0004)$. However no significant difference was found for $A \beta_{1-40}$. Post-hoc analyses demonstrated that the $\mathrm{AD}$ brain fractions had significantly higher levels of $\mathrm{A} \beta_{\mathrm{n}-40}$ compared to control tissue and significantly higher levels of $A \beta_{1-42}$ and $A \beta_{n-42}$ compared to both control and FTLD tissue.

\section{SELDI-TOF MS analysis of Aß in human brain homogenate}

Profiling of the human brain homogenates using WO2 in conjunction with SELDI-TOF MS indicated that the monomeric band resolvable by western blot consisted of a number of nterminally truncated $A \beta$ peptides ranging from $A \beta_{5-42}$ through $A \beta_{1-42}$ (Fig. 2a). A comparison between the expected molecular weight and observed molecular weights of the A $\beta$ peptides observed in the spectra is outlined in Table 3. As expected $A \beta_{1-42}$ was the predominant species observed in the sporadic $\mathrm{AD}$ brains however $\mathrm{A} \beta_{4-42}$ was also observable at near equivalent levels, despite being largely overlooked in the literature whilst more widely studied species such as pEA $\beta_{3-42}$ were only observable at low levels (Fig. 2b). A peak observed with an average mass of $4329 \mathrm{Da}$ could be attributed to either $\mathrm{A} \beta_{3-42}$ (4328 Da) or $\mathrm{A} \beta_{1-40}(4330 \mathrm{Da})$ as the resolution of the SELDI-TOF MS would not allow for a distinction to be made. However subsequent analysis of the AD homogenate with G210, an $A \beta_{40}$ specific antibody, showed no peaks consistent with any $A \beta_{n-40}$ species unless the homogenate was spiked with synthetic $A \beta_{1-40}$ prior to analysis (Fig. 2c). Whilst $A \beta_{1-40}$ was not observed using G210, low levels of $A \beta_{1-42}$ were observable in the $A D$ tissue; likely the result of non-specific binding. 
Comparative analysis of these $A \beta$ species showed that there were significant differences across the groups for $A \beta_{4-42}(p=0.0313), p E A \beta_{3-42}(p=0.0154), A \beta_{3-42}(p=0.0090), A \beta_{2-42}(p$ $=0.0014)$, and $A \beta_{1-42}(p=0.0028)$, however no significant difference was observed across the groups for $A \beta_{5-42}$ (Fig. 3). Post-hoc analyses indicated that there were significantly higher levels of $\mathrm{pEA} \beta_{3-42}$ and $\mathrm{A} \beta_{3-42}$ in the $\mathrm{AD}$ brain homogenate compared with control tissue and significantly higher $A \beta_{2-42}$ and $A \beta_{1-42}$ in the $A D$ tissue compared to both FTLD and control homogenate.

\section{Analysis of Familial AD brain homogenates}

Specific demographic information pertaining to the fAD brain homogenates is outlined in Table 4. Analysis of the fAD homogenates using western blot and SELDI-TOF MS showed that monomeric $A \beta$ profiles in the cortical tissue of those individuals with presenilin point mutations were indistinguishable from those observed in sporadic cases (Fig. $4 \mathbf{a} \& \mathbf{b}$ ). The deletion of Exon nine $(\Delta \mathrm{E} 9)$ however resulted in an $\mathrm{A} \beta$ profile distinct from the sporadic cases. Like sporadic $\mathrm{AD}$, the $\Delta \mathrm{E} 9$ homogenate showed an array of $\mathrm{N}$-terminally truncated $\mathrm{A} \beta$ isoforms however unlike sporadic $\mathrm{AD}$, the isoforms in the $\Delta \mathrm{E} 9$ homogenate were $\mathrm{n}-40$ species $\left(A \beta_{4-40}, A \beta_{2-40}, A \beta_{1-40}\right)$ (Fig. 4c). Furthermore the $\Delta E 9$ homogenate showed $A \beta_{1-38}$, a species not observed in other fAD or AD spectra. A comparison between the expected molecular weight and observed molecular weights of the $A \beta$ peptides observed in the spectra is outlined in Table 5. Moreover the levels of $\mathrm{A} \beta$ observed in the $\Delta \mathrm{E} 9$ homogenate were higher than those observed in the other fAD and SAD cases, when analysed by western, xMAP and SELDI-TOF MS. 


\section{Western blot analysis of synaptophysin levels}

Synaptophysin levels in the brain homogenates were assessed, using western blots, as a general measure of neuronal health. Comparative analysis of these blots indicated that brain homogenates affected by AD, FTLD and fAD all had significantly lower levels of synaptophysin than the control tissue $(\mathrm{p}<0.0001)($ Fig. 5a \& b).

The association between synaptophysin levels and $A \beta$ levels as measured by western blot, xMAP and SELDI-TOF MS were assessed using Pearson's correlations (Table 6). These analyses revealed that there were significant negative correlations between synaptophysin levels and both 'monomeric' $\mathrm{A} \beta(\mathrm{r}=-0.46, \mathrm{p}=0.0168)$ and 'dimeric' $\mathrm{A} \beta(\mathrm{r}=-0.51, \mathrm{p}=$ 0.0083) as measured by western blot. Significant negative correlations were also observed between synaptophysin levels and xMAP measures of $A \beta_{1-40}(r=-0.59, p=0.0015), A \beta_{n-40}(r$ $=-0.62, \mathrm{p}=0.0007)$ and $\mathrm{A} \beta_{\mathrm{n}-42}(\mathrm{r}=-0.41, \mathrm{p}=0.0380)$, but not between $\mathrm{A} \beta_{1-42}$ and synaptophysin levels. Analyses of the relationships between the individual A $\beta$ species, as measured by SELDI-TOF MS, and synaptophysin levels showed that there was a significant negative correlation between $A \beta_{3-42}$ and synaptophysin $(r=-0.54, p=0.0040)$. However significant correlations with synaptophysin were not observed for $A \beta_{5-42}, A \beta_{4-42}, p E A \beta_{3-42}$,

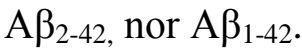

\section{Comparisons across techniques}

Comparisons across the three A $\beta$ measuring techniques were made using Pearson's correlations (Table 7). 'Monomeric' A $\beta$ measured by western blot was found to be positively correlated with xMAP measures of $A \beta_{1-40}(r=0.72, p<0.0001), A \beta_{n-40}(r=0.52, p=0.0060)$ and $\mathrm{A} \beta_{\mathrm{n}-42}(\mathrm{r}=0.43, \mathrm{p}=0.0277)$. No significant association between 'monomeric' $\mathrm{A} \beta$ measured by western and xMAP measure of $A \beta_{1-42}$ was observed. 
Comparisons between the A $\beta$ species measured by xMAP and those measured by SELDITOF MS showed that there were significant positive correlations between levels of $A \beta_{1-40}(r$ $=0.85, \mathrm{p}<0.0001)$ and $\mathrm{A} \beta_{1-42}(\mathrm{r}=0.55, \mathrm{p}=0.0033)$. Comparisons between the xMAP measure of $A \beta_{n-42}$ and SELDI-TOF MS $A \beta_{n-42}$ species, including $A \beta_{1-42}$, were made by summing the peak intensities of the N-terminally truncated $A \beta$ species observable by SELDI. This analysis revealed that there was also a significant positive correlation between the two $\mathrm{A} \beta_{\mathrm{n}-42}$ measures $(\mathrm{r}=0.55, \mathrm{p}=0.0033)$.

Finally comparisons were also undertaken between levels of $A \beta$ as measured by western blot and SELDI-TOF MS respectively. Peak intensities of the various A $\beta$ isoforms observable using SELDI-TOF MS were summed to account for the less specific separation of individual $\mathrm{A} \beta$ isoforms via western blot. Pearson's correlation showed that there was a significant positive correlation between the summed $\mathrm{A} \beta$ peak intensities and the 'monomeric' $\mathrm{A} \beta$ observable with western blot $(\mathrm{r}=0.53, \mathrm{p}=0.0052)$.

\section{Observing dimeric Aß using SELDI-TOF MS}

Attempts were also made to compare the levels of 'dimeric' $\mathrm{A} \beta$ observed using western blot with 'dimeric' $A \beta$ observable within the MS spectra. However analysis of the MS spectral range in which 'dimeric' $A \beta$ should be visible revealed no observable peaks consistent with any 'dimeric' $A \beta$ isoforms (Fig. 6a). The inability to observe the 'dimeric' $A \beta$ species, observable by western, within the SELDI spectra raised the possibility that the confirmation of the 'dimeric' isoforms may have blocked the WO2 epitope and thus prevented binding from occurring or alternatively that the high abundance of monomeric isoforms were saturating the detector, thus precluding dimeric species from being readily observable. This 
idea was tested by analysing the AD cortical tissue spiked with $100 \mathrm{fmol}$ of di-tyrosine crosslinked $A \beta_{1-40} \mathrm{Met}_{35}(\mathrm{O})$ (Fig. 6b). The ability of this methodology to analyse dimeric $A \beta_{1-42}$ has been reported previously [49]. The femto-molar concentrations of synthetic dimeric $\mathrm{A} \beta_{1-}$ 40 were readily observable within the spectra. Moreover the concentrations of synthetic dimer observable by SELDI MS were orders of magnitude lower than those observable by western blots (Fig. 6c). These findings raised the possibility that the lack of 'dimeric' species observed was not an aberration of the SELDI spectra, but rather that the presence of 'dimeric' species within the western blots were confounding these results.

\section{'Dimeric' Aß and SDS-PAGE}

Previous reports in the literature have reported that SDS induces $\beta$-sheet formation by A $\beta$ which increases $A \beta$ toxicity [46], promotes the formation of $A \beta$ gobulomers [11], and prompts the formation of $\mathrm{A} \beta$ trimers [3]. Given these previous reports, the role of SDS in the formation of 'dimeric' $\mathrm{A} \beta$ was tested. $\mathrm{AD}$ brain homogenates were prepared in sample buffer, with concentrations of SDS ranging from $0.5 \%$ to $4 \%$, before being analysed by western blot (Fig. 7a). Densitometric analysis of the blots showed that there was a significant difference in the levels of observable 'dimeric' $A \beta$ across the groups (Fig. 7b). Whilst there was a readily observable trend towards more intense 'dimeric' bands in the higher SDS conditions post hoc analyses showed that there were no significant differences across the concentrations. However when this experiment was repeated using synthetic $A \beta_{1-42}$ not only was there a significant difference across the range of SDS concentrations, but there was also a significant difference between specific concentrations; there was significantly greater dimeric $\mathrm{A} \beta$ in $2 \%$ SDS than $0.5 \%$, there was significantly greater dimeric $\mathrm{A} \beta$ in $3 \%$ SDS than $0.5 \%$ SDS, and $1 \%$ SDS and there was significantly greater dimeric A $\beta$ in $4 \%$ SDS than $0.5 \%$ SDS, $1 \%$ SDS and 2\% SDS (Fig. 7c \& d). No significant differences were observed in monomeric 
A $\beta$ levels (Supplementary Fig. 1). in Attempts were made to analyse whether SDS induced 'dimeric A $\beta$ ' could be observed using SELDI MS however interactions between SDS and the array surface prevented this line of investigation (data not shown).

\section{Discussion}

\section{Discussion}

Consistent with previous reports $[33,19,44]$, the current MS investigation demonstrated that the $\mathrm{AD}$-affected cortical tissue is laden with a wide spectrum of $\mathrm{N}$-terminally truncated $\mathrm{A} \beta_{\mathrm{n}-42}$ peptides, including $A \beta_{1-42}, A \beta_{2-42}, p E A \beta_{3-42}, A \beta_{3-42}, A \beta_{4-42}$ and $A \beta_{5-42}$. Of these, $A \beta_{1-42}$ and $\mathrm{A} \beta_{4-42}$ were the predominant species detected; a finding which was consistent with earlier reports $[33,19,44]$. To date, $A \beta_{1-42}$ has received the lion's share of the attention whilst $A \beta_{4-42}$ has largely been overlooked, despite both peptides being isolated from the AD-affected brain over 25 years ago [23]. The tendency for the scientific community to overlook $A \beta_{4-42}$ potentially stems from the faster aggregation kinetics and higher $\beta$-sheet formation associated with $N$-terminally truncated $A \beta$ isoforms, making $A \beta_{4-42}$ a difficult peptide to synthesize [31,24]; a fact that the current authors can anecdotally confirm.

Familial forms of the disease, resulting from point mutations in PSEN1, resulted in cortical monomeric $A \beta$ profiles which were indistinguishable from those observed in sporadic $A D$, albeit occurring some 10 years earlier in the subject's life. However the brain tissue arising from the carrier of a $\Delta E 9$ exhibited $p E A \beta_{3-42}$ and $A \beta_{1-42}$ alongside a predominant $A \beta_{1-40}$ peak and a series of $\mathrm{N}$-terminally truncated $\mathrm{A} \beta_{\mathrm{n}-40}$ isoforms. The $\Delta \mathrm{E} 9$ mutation has been reported as having an unusual but characteristic pattern of $\mathrm{A} \beta$ deposition known as 'cotton wool' plaques and has been shown to result in higher ratios between $A \beta_{1-40}$ and $A \beta_{1-42}$ in human 
cortical tissue than those observed in sporadic AD and other PS-1 mutations [22]. Higher ratios between $A \beta_{1-40}$ and $A \beta_{1-42}$ have also been observed in mouse embryonic fibroblasts with the $\Delta \mathrm{E} 9$ mutation compared to other PS1 variants [4]. A majority of histopathological investigations conducted to date have reported a significant increase in $A \beta_{1-42}$ observable within the 'cotton wool plaques' $[17,56]$; however, in some individual cases $A \beta_{1-40}$ has been shown to be the predominant species [56]. On the surface these reports appear to contradict the current findings of abundant $A \beta_{n-40}$ species within $\Delta \mathrm{E} 9$ affected tissue, however the methodologies utilized in the current study would not have disrupted the abundant $A \beta_{1-42}$ sequestered in plaques and raise the possibility that the $\Delta \mathrm{E} 9$ mutation results in increased levels of soluble $\mathrm{A} \beta_{\mathrm{n}-40}$ species.

The adaptation of the xMAP INNO-BIA assays in the current study demonstrated that such high-throughput techniques can successfully be used to assess $A \beta$ levels in human cortical tissue. Significant correlations between A $\beta$ levels as measured by xMAP, Western blot or SELDI-TOF MS suggest that these techniques appear to be measuring overlapping pools of $A \beta$, at least with regard to $A \beta_{n-42}$ species. The significantly higher levels of $A \beta_{n-40}$ species observed in the AD fractions using the xMAP assays were somewhat surprising as they did not correspond to the A $\beta$ profiles observed by SELDI-TOF MS. This discrepancy could be due to differences in the antibodies used in the two methods; however, the observation of $\mathrm{A} \beta_{\mathrm{n}-40}$ species in the familial tissue suggests that this was unlikely. Alternatively the discrepancy might arise from the xMAP antibodies either binding larger aggregates of $\mathrm{A} \beta$ / $\mathrm{APP}$, that fall outside the range of MS detection, or $\mathrm{A} \beta$ species other than the $\mathrm{A} \beta_{\mathrm{n}-40}$ species that the antibodies are reported to be specific for. These notions are however somewhat difficult to evaluate, due to the fact that xMAP works in a proverbial "black box", measuring a simple immunoresponse that gives no indication to the possible range of species being 
detected; although, future investigations that can adapt the xMAP antibodies for analysis using SELDI-TOF MS may provide a better approach.

At this stage it is important to note the differences between SELDI-TOF MS and more traditional MS investigations into A $\beta$ levels in human brain. Traditional MS studies rely on serial high-speed centrifugations of the human samples in buffers such as TBS / PBS and formic acid before the 'soluble' $\mathrm{A} \beta$ is collected and analysed using immunoprecipitation (IP) with an $A \beta$-specific antibody $[29,33]$. The captured $A \beta$ is subsequently eluted from the IP beads and freeze-dried before being resuspended and analysed using MS to determine the proteomic profile of $A \beta$ in the human brain. Unlike traditional MS techniques, SELDI-TOF MS involves an on-array IP which eradicates the need for samples to undergo centrifugation, elution, freeze-drying and re-suspension. Instead the $A \beta$ in the samples binds directly to the $\mathrm{A} \beta$-specific antibodies bound to the array surface, thus allowing a more direct analysis of $A \beta$ levels within the human brain homogenates.

Investigations into $A \beta_{1-40}$ levels in sporadic $A D$ tissue resulted in a number of contradictory observations. Analysis by SELDI-TOF MS with the $\mathrm{A} \beta_{40}$ specific antibody (G2-10) suggested that the peak observed at $4329 \mathrm{Da}$ in the $\mathrm{AD}$ tissue belonged to $\mathrm{A} \beta_{3-42}$. Analysis by xMAP however, suggested that there was more than $100 \mathrm{pg} / \mathrm{mL}$ of $\mathrm{A} \beta_{1-40}$ and more than 200 $\mathrm{pg} / \mathrm{mL}$ of $\mathrm{A} \beta_{\mathrm{n}-40}$ within the AD tissue, levels which the SELDI-TOF MS was more than capable of measuring. The lack of $A \beta_{\mathrm{n}-40}$ species observable within the MS spectra raises the question of whether the xMAP system is measuring aggregated $A \beta_{n-40}$ species which lie outside the dynamic range of SELDI-TOF MS or whether the signals are the result of nonspecific binding occurring with other proteins in the samples. Previous MS studies have reported that $A \beta_{1-40}$ is readily observable when formic acid extractions are used to disrupt $A \beta$ 
plaques, a finding which has been confirmed by MS/MS techniques [33,29]. Additionally, a number of MS studies report observing $A \beta_{1-40}$ within the soluble fractions of brain often in the midst of a range of $A \beta_{n-42}$ isoforms $[19,44]$; however, like the current study, these studies invariably relied on $\mathrm{m} / \mathrm{z}$ for the identification of these peaks, raising the possibility that soluble levels of $A \beta_{3-42}$ have erroneously been reported as $A \beta_{1-40}$ in the literature.

The formation of small order $A \beta$ oligomers has long been thought of as a fundamental stage in the pathogenesis of $\mathrm{AD}$ and over the past decade these oligomeric species have become an attractive target for $\mathrm{AD}$ therapeutics [52,38]. Consistent with previously published reports, bands consistent with 'dimeric' $\mathrm{A} \beta$ were readily observable in western blots of both synthetic $\mathrm{A} \beta$ and $\mathrm{AD}$-affected cortical tissue. However, peaks consistent with 'dimeric' $\mathrm{A} \beta$ were not observed in the MS spectra arising from AD tissue, despite the abundance of monomeric $A \beta$ isoforms. It is possible that differences in the sample buffer used for western blots and SELDI-TOF MS, namely the presence of urea in the MS sample buffer, may have been a limiting factor in the observation of small order $A \beta$ oligomers in the MS spectra. However as the methodology had previously been utilised to observe $A \beta$ oligomers in mouse brain homogenates [7] and human blood [50], in addition to the capture of synthetically derived dimeric $A \beta$ in the present study, it is unlikely that the presence of urea precluded the observation of dimeric $A \beta$ in the MS spectra. With this in mind, the lack of observable dimeric $\mathrm{A} \beta$ in the current MS analysis means that a MS spectrum of brain-derived, low-order oligomeric $A \beta$ remains unreported in the scientific literature.

Interactions between SDS and $\mathrm{A} \beta$ have been widely reported in the literature with a number of studies reporting that SDS induces $A \beta \beta$-sheet formation [46,35], increases $A \beta$ toxicity [46], $A \beta$ globulomer formation [11], and $A \beta$ trimer formation [3]. The findings of the current 
study indicate that SDS is also capable of inducing the dimerization of $A \beta$, both in its synthetic form and in isoforms derived from $\mathrm{AD}$-affected cortical tissue. It is noted that whilst significantly different, the SDS induction of dimeric $\mathrm{A} \beta$ appeared to be less responsive in the brain homogenates when compared to experiments using synthetic $A \beta$. This difference is likely to be due to variations in the complexity of the proteomic environments and the availability of additional $A \beta$ interactions in the two experimental settings. The current findings are in line with a recent investigation by Rangachari et al [35] who reported that $A \beta_{1-}$ 42 undergoes rapid conformational changes in the presence of SDS leading to conversion of monomeric $A \beta_{1-42}$ to bands consistent with low-order oligomeric $A \beta$ species, ranging from dimer through tetramer. Additionally, studies using 7PA2 cells which have shown that bands previously reported as corresponding to 'dimeric' and 'trimeric' $\mathrm{A} \beta$ can also be increased through the inhibition of BACE1 [34]. However rather than increasing the rate of $A \beta$ oligomerisation, inhibition of BACE1 in the cells reportedly led to differential processing of APP, resulting in a number of larger APP/A $\beta$ fragments spanning the $\beta$-secretase site.

It has been widely established that $A \beta$ is a pleomorphic peptide whose structure has been found to be dependent on its environmental context, with metals, lipid membranes, salts, detergents, and $\mathrm{pH}$ levels all significantly affecting $\mathrm{A} \beta$ 's structure. In a biological context protein/peptide structure and function are intimately linked, consequently not only does the environment of the peptide modify its structure but it will also impact on its subsequent toxicity $[3,46,35,11,8,41]$. Such environmental effects make isolating and analysing small order oligomers of $\mathrm{A} \beta$ problematic as each proteomic technique exerts a different set of environmental constraints on the $A \beta$ peptide, some resulting in the formation of species that may not always be observed in a native setting. Therefore ideally it would be best if methods could be developed to identify various forms of $A \beta$ in situ as any manipulation has the 
potential to introduce artefacts. However given that these methods do not yet exist, in this work we have striven to restrict manipulation of the samples by using simple brain homogenates and the limited sample preparation required by SELDI-TOF MS. With this in mind, the lack of small order oligomers observed using SELDI TOF MS suggest that prevailing notions regarding the importance of dimeric $A \beta$ may be resulting from an over interpretation of the published literature rather than an accurate depiction of A $\beta$ 's structure and role in $\mathrm{AD}$ pathogenesis. The current findings do however reaffirm that given the right context $A \beta$, from human tissue, is capable of forming small order oligomeric structures. However, whether these structures are stable and isolatable or whether the structural plasticity of these $A \beta$ assemblies makes attempts to isolate them futile remains to be seen.

The reliance on low resolution analytical techniques in the formation of the $A \beta$-centric theory of AD has potentially led to an overly simplistic understanding of APP processing and A $\beta$ oligomerisation. For over a decade this knowledge has been used as the cornerstone of AD therapeutics which has repeatedly attempted to regulate $A \beta$ oligomerisation and aggregation within the AD brain; however, to date these attempts have met with limited success. The advent and advances of high-resolution techniques, such as MS, provide researchers with the tools to re-examine a number of the now widely-held assumptions of AD pathogenesis. These techniques can now be utilized to dispel common misconceptions in the field and gain a more thorough understanding of $\mathrm{A} \beta$ 's role in $\mathrm{AD}$ pathology, a knowledge that could potentially be translated into a more rational and effective approach to the treatment of this devastating disease. 


\section{Disclosures}

This work was funded by National Health and Medical Research Council of Australia. 


\section{References}

1. Barnham KJ, Ciccotosto GD, Tickler AK, Ali FE, Smith DG, Williamson NA, Lam YH, Carrington D, Tew D, Kocak G, Volitakis I, Separovic F, Barrow CJ, Wade JD, Masters CL, Cherny RA, Curtain CC, Bush AI, Cappai R (2003) Neurotoxic, redoxcompetent Alzheimer's b-amyloid is released from lipid membrane by methionine oxidation. J Biol Chem 278 (44):42959-42965

2. Barnham KJ, Haeffner F, Ciccotosto GD, Curtain CC, Tew D, Mavros C, Beyreuther K, Carrington D, Masters CL, Cherny RA, Cappai R, Bush AI (2004) Tyrosine gated electron transfer is key to the toxic mechanism of Alzheimer's disease b-amyloid. Faseb J 18 (12):1427. doi:10.1096/fj.04-1890fje

3. Bitan G, Kirkitadze MD, Lomakin A, Vollers SS, Benedek GB, Teplow DB (2003) Amyloid b-protein (Ab) assembly: Ab40 and Ab42 oligomerize through distinct pathways. Proc Natl Acad Sci U S A 100 (1):330-335

4. Cacquevel M, Aeschbach L, Houacine J, Fraering PC (2012) Alzheimer's Disease-Linked Mutations in Presenilin-1 Result in a Drastic Loss of Activity in Purified $\gamma$-Secretase Complexes. PLoS ONE 7 (4):e35133. doi:10.1371/journal.pone.0035133

5. Carson RT, Vignali DAA (1999) Simultaneous quantitation of 15 cytokines using a multiplexed flow cytometric assay. Journal of Immunological Methods 227 (1-2):4152. doi:10.1016/s0022-1759(99)00069-1

6. Consensus recommendations for the postmortem diagnosis of Alzheimer's disease. The National Institute on Aging, and Reagan Institute Working Group on Diagnostic Criteria for the Neuropathological Assessment of Alzheimer's Disease (1997). Neurobiol Aging 18 (4 Suppl):S1-2

7. Crouch PJ, Hung LW, Adlard PA, Cortes M, Lal V, Filiz G, Perez KA, Nurjono M, Caragounis A, Du T, Laughton K, Volitakis I, Bush AI, Li QX, Masters CL, Cappal R, Cherny RA, Donnelly PS, White AR, Barnham KJ (2009) Increasing Cu bioavailability inhibits Ab oligomers and tau phosphorylation. Proc Natl Acad Sci U S A 106 (2):381-386. doi:10.1073/pnas.0809057106

8. Curtain CC, Ali F, Volitakis I, Cherny RA, Norton RS, Beyreuther K, Barrow CJ, Masters CL, Bush AI, Barnham KJ (2001) Alzheimer's disease amyloid-b binds copper and zinc to generate an allosterically ordered membrane-penetrating structure containing superoxide dismutase-like subunits. J Biol Chem 276:20466-20473 
9. Dickson DW, Crystal HA, Bevona C, Honer W, Vincent I, Davies P (1995) Correlations of synaptic and pathological markers with cognition of the elderly. Neurobiology of Aging 16 (3):285-298

10. Figurski MJ, Waligórska T, Toledo J, Vanderstichele H, Korecka M, Lee VMY, Trojanowski JQ, Shaw LM (2012) Improved protocol for measurement of plasma $\beta$ amyloid in longitudinal evaluation of Alzheimer's Disease Neuroimaging Initiative study patients. Alzheimer's \& dementia : the journal of the Alzheimer's Association 8 (4):250-260

11. Gellermann GP, Byrnes H, Striebinger A, Ullrich K, Mueller R, Hillen H, Barghorn S (2008) Ab-globulomers are formed independently of the fibril pathway. Neurobiol Dis 30 (2):212-220

12. Hardy J, Selkoe DJ (2002) The amyloid hypothesis of Alzheimer's disease: progress and problems on the road to therapeutics. Science (New York, NY) 297 (5580):353-356. doi:10.1126/science.1072994

13. Hung LW, Ciccotosto GD, Giannakis E, Tew DJ, Perez K, Masters CL, Cappai R, Wade JD, Barnham KJ (2008) Amyloid-b peptide (Ab) neurotoxicity is modulated by the rate of peptide aggregation: Abeta dimers and trimers correlate with neurotoxicity. $\mathrm{J}$ Neurosci 28 (46):11950-11958

14. Ida N, Hartmann T, Pantel J, Schroder J, Zerfass R, Forstl H, Sandbrink R, Masters CL, Beyreuther K (1996) Analysis of heterogeneous b-A4 peptides in human cerebrospinal fluid and blood by a newly developed sensitive western blot assay. Journal of Biological Chemistry 271:22908-22914

15. Karran E (2012) Current status of vaccination therapies in Alzheimer's disease. Journal of Neurochemistry 123 (5):647-651. doi:10.1111/jnc.12009

16. Klyubin I, Walsh DM, Lemere CA, Cullen WK, Shankar GM, Betts V, Spooner ET, Jiang L, Anwyl R, Selkoe DJ, Rowan MJ (2005) Amyloid-b protein immunotherapy neutralizes Ab oligomers that disrupt synaptic plasticity in vivo. Nat Med 11 (5):556561

17. Koivunen J, Verkkoniemi A, Aalto S, Paetau A, Ahonen J-P, Viitanen M, Någren K, Rokka J, Haaparanta M, Kalimo H, Rinne JO (2008) PET amyloid ligand [11C]PIB uptake shows predominantly striatal increase in variant Alzheimer's disease. Brain 131 (7):1845-1853. doi:10.1093/brain/awn107

18. Kok WM, Scanlon DB, Karas JA, Miles LA, Tew DJ, Parker MW, Barnham KJ, Hutton CA (2009) Solid-phase synthesis of homodimeric peptides: preparation of covalently- 
linked dimers of amyloid-b peptide. Chem Commun (Camb) (41):6228-6230. doi:10.1039/b912784d

19. Lewis H, Beher D, Cookson N, Oakley A, Piggott M, Morris CM, Jaros E, Perry R, Ince P, Kenny RA, Ballard CG, Shearman MS, Kalaria RN (2006) Quantification of Alzheimer pathology in ageing and dementia: age-related accumulation of amyloid$\beta(42)$ peptide in vascular dementia. Neuropathology and Applied Neurobiology 32 (2):103-118. doi:10.1111/j.1365-2990.2006.00696.x

20. Lui JK, Laws SM, Li QX, Villemagne VL, Ames D, Brown B, Bush AI, De Ruyck K, Dromey J, Ellis KA, Faux NG, Foster J, Fowler C, Gupta V, Hudson P, Laughton K, Masters CL, Pertile K, Rembach A, Rimajova M, Rodrigues M, Rowe CC, Rumble R, Szoeke C, Taddei K, Taddei T, Trounson B, Ward V, Martins RN, Grp AR (2010) Plasma Amyloid-b as a Biomarker in Alzheimer's Disease: The AIBL Study of Aging. J Alzheimers Dis 20 (4):1233-1242. doi:10.3233/jad-2010-090249

21. Mackenzie IR, Neumann M, Baborie A, Sampathu DM, Du Plessis D, Jaros E, Perry RH, Trojanowski JQ, Mann DM, Lee VM (2011) A harmonized classification system for FTLD-TDP pathology. Acta Neuropathol 122 (1):111-113. doi:10.1007/s00401-0110845-8

22. Mann DM, Takeuchi A, Sato S, Cairns NJ, Lantos PL, Rossor MN, Haltia M, Kalimo H, Iwatsubo T (2001) Cases of Alzheimer's disease due to deletion of exon 9 of the presenilin-1 gene show an unusual but characteristic b-amyloid pathology known as 'cotton wool' plaques. Neuropathology and Applied Neurobiology 27 (3):189-196

23. Masters CL, Simms G, Weinman NA, Multhaup G, McDonald BL, Beyreuther K (1985) Amyloid plaque core protein in Alzheimer disease and Down syndrome. Proc Natl Acad Sci U S A 82:4245-4249

24. McColl G, Roberts BR, Gunn AP, Perez KA, Tew DJ, Masters CL, Barnham KJ, Cherny RA, Bush AI (2009) The Caenorhabditis elegans Ab 1-42 model of Alzheimer disease predominantly expresses Ab 3-42. J Biol Chem 284 (34):22697-22702. doi:10.1074/jbc.C109.028514

25. McKhann GM, Albert MS, Grossman M, Miller B, Dickson D, Trojanowski JQ (2001) Clinical and pathological diagnosis of frontotemporal dementia: report of the Work Group on Frontotemporal Dementia and Pick's Disease. Arch Neurol 58 (11):18031809. doi:nsa10000 [pii] 
26. McLean CA, Cherny RA, Fraser FW, Fuller SJ, Smith MJ, Beyreuther K, Bush AI, Masters CL (1999) Soluble pool of Ab amyloid as a determinant of severity of neurodegeneration in Alzheimer's disease. Ann Neurol 46:860-866

27. Mintun MA, Larossa GN, Sheline YI, Dence CS, Lee SY, Mach RH, Klunk WE, Mathis CA, DeKosky ST, Morris JC (2006) [11C]PIB in a nondemented population: potential antecedent marker of Alzheimer disease. Neurology 67 (3):446-452. doi:10.1212/01.wnl.0000228230.26044.a4

28. Montine TJ, Phelps CH, Beach TG, Bigio EH, Cairns NJ, Dickson DW, Duyckaerts C, Frosch MP, Masliah E, Mirra SS, Nelson PT, Schneider JA, Thal DR, Trojanowski JQ, Vinters HV, Hyman BT (2012) National Institute on Aging-Alzheimer's Association guidelines for the neuropathologic assessment of Alzheimer's disease: a practical approach. Acta Neuropathol 123 (1):1-11. doi:10.1007/s00401-011-0910-3

29. Moore B, Chakrabarty P, Levites Y, Kukar T, Baine A-M, Moroni T, Ladd T, Das P, Dickson D, Golde T (2012) Overlapping profiles of Ab peptides in the Alzheimer's disease and pathological aging brains. Alzheimer's Research \& Therapy 4 (3):18

30. Olsson A, Vanderstichele H, Andreasen N, De Meyer G, Wallin A, Holmberg B, Rosengren L, Vanmechelen E, Blennow K (2005) Simultaneous Measurement of $\beta$ Amyloid(1-42), Total Tau, and Phosphorylated Tau (Thr181) in Cerebrospinal Fluid by the xMAP Technology. Clinical Chemistry 51 (2):336-345. doi:10.1373/clinchem.2004.039347

31. Pike CJ, Overman MJ, Cotman CW (1995) Amino-terminal deletions enhance aggregation of b-amyloid peptides in vitro. Journal of Biological Chemistry 270:23895-23898

32. Podlisny MB, Ostaszewski BL, Squazzo SL, Koo EH, Rydell RE, Teplow DB, Selkoe DJ (1995) Aggregation of secreted amyloid beta-protein into sodium dodecyl sulfatestable oligomers in cell culture. J Biol Chem 270 (16):9564-9570

33. Portelius E, Bogdanovic N, Gustavsson MK, Volkmann I, Brinkmalm G, Zetterberg H, Winblad B, Blennow K (2010) Mass spectrometric characterization of brain amyloid beta isoform signatures in familial and sporadic Alzheimer's disease. Acta Neuropathol 120 (2):185-193. doi:10.1007/s00401-010-0690-1

34. Portelius E, Olsson M, Brinkmalm G, Ruetschi U, Mattsson N, Andreasson U, Gobom J, Brinkmalm A, Holtta M, Blennow K, Zetterberg H (2013) Mass Spectrometric Characterization of Amyloid-beta Species in the 7PA2 Cell Model of Alzheimer's 
Disease. Journal of Alzheimer's disease : JAD 33 (1):85-93. doi:10.3233/jad-2012120994

35. Rangachari V, Moore BD, Reed DK, Sonoda LK, Bridges AW, Conboy E, Hartigan D, Rosenberry TL (2007) Amyloid-beta(1-42) rapidly forms protofibrils and oligomers by distinct pathways in low concentrations of sodium dodecylsulfatet. Biochemistry 46 (43):12451-12462

36. Roher AE, Chaney MO, Kuo YM, Webster SD, Stine WB, Haverkamp LJ, Woods AS, Cotter RJ, Tuohy JM, Krafft GA, Bonnell BS, Emmerling MR (1996) Morphology and toxicity of Ab-(1-42) dimer derived from neuritic and vascular amyloid deposits of Alzheimer's disease. J Biological Chem 271:20631-20635

37. Rowe CC, Ng S, Ackermann U, Gong SJ, Pike K, Savage G, Cowie TF, Dickinson KL, Maruff P, Darby D, Smith C, Woodward M, Merory J, Tochon-Danguy H, O'Keefe G, Klunk WE, Mathis CA, Price JC, Masters CL, Villemagne VL (2007) Imaging beta-amyloid burden in aging and dementia. Neurology 68 (20):1718-1725

38. Selkoe DJ (2011) Resolving controversies on the path to Alzheimer's therapeutics. Nat Med 17 (9):1060-1065

39. Shankar GM, Li S, Mehta TH, Garcia-Munoz A, Shepardson NE, Smith I, Brett FM, Farrell MA, Rowan MJ, Lemere CA, Regan CM, Walsh DM, Sabatini BL, Selkoe DJ (2008) Amyloid-beta protein dimers isolated directly from Alzheimer's brains impair synaptic plasticity and memory. Nat Med 14 (8):837-842

40. Shaw LM, Vanderstichele H, Knapik-Czajka M, Clark CM, Aisen PS, Petersen RC, Blennow K, Soares H, Simon A, Lewczuk P, Dean R, Siemers E, Potter W, Lee VM, Trojanowski JQ (2009) Cerebrospinal fluid biomarker signature in Alzheimer's disease neuroimaging initiative subjects. Ann Neurol 65 (4):403-413. doi:10.1002/ana.21610

41. Simmons LK, May PC, Tomaselli KJ, Rydel RE, Fuson KS, Brigham EF, Wright S, Lieberburg I, Becker GW, Brems DN, al. e (1994) Secondary structure of amyloid b peptide correlates with neurotoxic activity in vitro. Molecular Pharmacology 45:373379

42. Skaff O, Jolliffe KA, Hutton CA (2005) Synthesis of the side chain cross-linked tyrosine oligomers dityrosine, trityrosine, and pulcherosine. The Journal of organic chemistry 70 (18):7353-7363. doi:10.1021/jo051076m

43. Smith DP, Smith DG, Curtain CC, Boas JF, Pilbrow JR, Ciccotosto GD, Lau TL, Tew DJ, Perez K, Wade JD, Bush AI, Drew SC, Separovic F, Masters CL, Cappai R, 
Barnham KJ (2006) Copper-mediated amyloid-beta toxicity is associated with an intermolecular histidine bridge. J Biol Chem 281 (22):15145-15154

44. Tabaton M, Piccini A (2005) Role of water-soluble amyloid-beta in the pathogenesis of Alzheimer's disease. International journal of experimental pathology 86 (3):139-145. doi:10.1111/j.0959-9673.2005.00428.x

45. Terry RD, Masliah E, Salmon DP, Butters N, DeTeresa R, Hill R, Hansen LA, Katzman $R$ (1991) Physical basis of cognitive alterations in Alzheimer's disease: synapse loss is the major correlate of cognitive impairment. Ann Neurol 30:572-580

46. Tew DJ, Bottomley SP, Smith DP, Ciccotosto GD, Babon J, Hinds MG, Masters CL, Cappai R, Barnham KJ (2008) Stabilization of neurotoxic soluble beta-sheet-rich conformations of the Alzheimer's disease amyloid-beta peptide. Biophysical journal 94 (7):2752-2766

47. Tickler AK, Barrow CJ, Wade JD (2001) Improved preparation of amyloid-b peptides using DBU as $\mathrm{N}^{\mathrm{a}}$-Fmoc deprotection reagent. J Pept Sci 7:488-494

48. Toledo J, Vanderstichele H, Figurski M, Aisen P, Petersen R, Weiner M, Jack C, Jagust W, Decarli C, Toga A, Toledo E, Xie S, Lee V, Trojanowski J, Shaw L (2011) Factors affecting $A \beta$ plasma levels and their utility as biomarkers in ADNI. Acta Neuropathologica 122 (4):401-413. doi:10.1007/s00401-011-0861-8

49. Villemagne VL, Perez KA, Pike KE, Kok WM, Rowe CC, White AR, Bourgeat P, Salvado O, Bedo J, Hutton CA, Faux NG, Masters CL, Barnham KJ (2010) Blood Borne Amyloid-beta Dimer Correlates With Clinical Markers of Alzheimer's Disease. Journal of Neuroscience 30 (18):6315-6322

50. Villemagne VL, Perez KA, Pike KE, Rowe CC, Masters CL, White AR, Bedo J, Faux NG, Barnham KJ (2010) Blood Borne Amyloid-beta Dimer Correlates With Clinical Markers of Alzheimer's Disease. Journal of Neuroscience 30 (18):6315-6322

51. Walsh DM, Klyubin I, Fadeeva JV, Cullen WK, Anwyl R, Wolfe MS, Rowan MJ, Selkoe DJ (2002) Naturally secreted oligomers of amyloid beta protein potently inhibit hippocampal long-term potentiation in vivo. Nature 416 (6880):535-539

52. Walsh DM, Selkoe DJ (2007) A beta oligomers - a decade of discovery. J Neurochem $101(5): 1172-1184$

53. Walsh DM, Townsend M, Podlisny MB, Shankar GM, Fadeeva JV, El Agnaf O, Hartley DM, Selkoe DJ (2005) Certain inhibitors of synthetic amyloid beta-peptide (Abeta) fibrillogenesis block oligomerization of natural Abeta and thereby rescue long-term potentiation. J Neurosci 25 (10):2455-2462 
54. Walsh DM, Tseng BP, Rydel RE, Podlisny MB, Selkoe DJ (2000) The oligomerization of amyloid beta-protein begins intracellularly in cells derived from human brain. Biochemistry 39 (35):10831-10839

55. Wang J, Dickson DW, Trojanowski JQ, Lee VM (1999) The levels of soluble versus insoluble brain $\mathrm{Ab}$ distinguish Alzheimer's disease from normal and pathologic aging. Exp Neurol 158:328-337

56. Yokota O, Terada S, Ishizu H, Ujike H, Ishihara T, Namba M, Hayashi Y, Nishinaka T, Namba R, Nakashima H, Ueda K, Checler F, Kuroda S (2003) Variability and heterogeneity in Alzheimer's disease with cotton wool plaques: a clinicopathological study of four autopsy cases. Acta Neuropathol 106 (4):348-356. doi:10.1007/s00401003-0737-7 
Tables

Table 1. Clinical information pertaining to the 26 individuals from whom brain tissue was collected. Data displayed as mean (SD).

\begin{tabular}{|c|c|c|c|c|}
\hline & $\begin{array}{l}\text { Control } \\
(\mathrm{n}=8)\end{array}$ & $\begin{array}{l}\mathrm{AD} \\
(\mathrm{n}=12)\end{array}$ & $\begin{array}{l}\text { FAD } \\
(n=3)\end{array}$ & $\begin{array}{l}\text { FTLD } \\
(n=3)\end{array}$ \\
\hline Male / Female & $4 / 4$ & $8 / 4$ & $1 / 2$ & $2 / 1$ \\
\hline Age at onset ${ }^{\dagger}$ & - & $67.38(15.13)$ & $47.33(8.08)$ & $51.33(14.50)$ \\
\hline Age at death & $72.26(8.10)$ & $77.20(9.71)$ & $56.93(8.35) *$ & $62.17(19.20)$ \\
\hline Brain Weight (g) & $1253.00(159.08)$ & $1122.33(78.40)$ & $1029.00(471.58)$ & $1027.33(232.47)$ \\
\hline PMI (hours) & $33.94(17.62)$ & $35.79(21.36)$ & $59.83(34.26)$ & $39.83(21.83)$ \\
\hline
\end{tabular}

Approximation from family $\mathrm{AD}(\mathrm{n}=8)$

PMI - Post mortem index

* Significantly different to $\mathrm{AD} \mathrm{p}<0.05$ 
Table 2. Levels of A $\beta$ in the brain homogenates as assessed by the adapted INNO-BIA xMAP assays. Data displayed as pg/mL mean (SD).

\begin{tabular}{|c|c|c|c|c|c|}
\hline & $\begin{array}{l}\text { Control } \\
(\mathbf{n}=\mathbf{8})\end{array}$ & $\begin{array}{l}\mathrm{AD} \\
(\mathrm{n}=12)\end{array}$ & $\begin{array}{l}\text { FTLD } \\
(\mathbf{n}=\mathbf{3})\end{array}$ & $\begin{array}{l}\text { FAD } \\
(\mathbf{n}=\mathbf{3})\end{array}$ & $\begin{array}{l}\text { ANOVA } \\
\text { p-value }\end{array}$ \\
\hline$A \beta 1-40$ & $42.00(16.05)$ & $113.10(82.18)$ & $63.15(57.64)$ & $257.27(258.78)$ & 0.0681 \\
\hline$A \beta 1-42$ & $127.49(136.72)$ & $525.10(208.80)^{* * *}$ & $46.64(29.30) \dagger$ & $280.02(161.21)$ & $<0.0001$ \\
\hline$A \beta n-40$ & $62.20(47.65)$ & $223.20(164.6)^{*}$ & $120.20(136.50)$ & $359.33(216.02)$ & 0.0443 \\
\hline$A \beta n-42$ & $440.07(539.86)$ & $1282.00(406.50)^{* *}$ & $263.7(229.5) \dagger$ & $1013.82(100.49)$ & 0.0004 \\
\hline
\end{tabular}

\footnotetext{
* Significantly different to control $\mathrm{p}<0.05$

** Significantly different to control $\mathrm{p}<0.01$

*** Significantly different to control $\mathrm{p}<0.001$

$\uparrow$ Significantly different to AD $\mathrm{p}<0.01$
} 
Table 3. Comparison between Expected MW and Observed MW of the A $\beta$ species observed in the AD tissue by SELDI-TOF MS. All MW data represent protonated average masses.

\begin{tabular}{cccc}
\hline A $\boldsymbol{\beta}$ Peptide & $\begin{array}{c}\text { Predicted } \\
\text { MW }\end{array}$ & $\begin{array}{c}\text { Observed } \\
\text { MW }\end{array}$ & $\boldsymbol{\Delta}$ MW \\
\hline A $\beta 5-42$ & 4052.65 & 4052.46 & 0.19 \\
$\mathrm{~A} \beta 4-42$ & 4199.83 & 4201.83 & 2.00 \\
$\mathrm{pEA} \beta 3-42$ & 4309.90 & 4312.60 & 2.70 \\
$\mathrm{~A} \beta 3-42$ & 4328.94 & 4329.81 & 0.87 \\
$\mathrm{~A} \beta 2-42$ & 4400.02 & 4403.74 & 3.72 \\
$\mathrm{~A} \beta 1-42$ & 4515.10 & 4515.90 & 0.80 \\
\hline
\end{tabular}

Table 4. Clinical information pertaining to the three familial Alzheimer's disease cases.

\begin{tabular}{llccccc}
\hline Carrier & Mutation & Age at onset* & Age at death & Gender & Brain Weight (g) & Evidence of CAA \\
\hline PSEN1 & LE9 & 38 & 48 & Female & 644.00 & Yes \\
PSEN1 & L219P & 52 & 64 & Female & 888.00 & Yes \\
PSEN1 & C236T & 52 & 58 & Male & 1555.00 & No \\
\hline
\end{tabular}

* Approximation from family

CAA - Congophilic amyloid angiopathy 
Table 5. Comparison between Expected MW and Observed MW of the A $\beta$ species observed in the $\triangle$ E9 fAD tissue by SELDI-TOF MS. All MW data represent protonated average masses.

\begin{tabular}{cccc}
\hline A $\boldsymbol{\beta}$ Peptide & $\begin{array}{c}\text { Predicted } \\
\mathbf{M} / \mathbf{W}\end{array}$ & $\begin{array}{c}\text { Observed } \\
\mathbf{M} / \mathbf{W}\end{array}$ & $\boldsymbol{\Delta} \mathbf{M} / \mathbf{W}$ \\
\hline $\mathrm{A} \beta 4-40$ & 4015.59 & 4016.22 & 0.63 \\
$\mathrm{~A} \beta 1-38$ & 4132.60 & 4134.59 & 1.99 \\
$\mathrm{~A} \beta 2-40$ & 4215.78 & 4216.12 & 0.34 \\
$\mathrm{pEA} \beta 3-42$ & 4309.90 & 4311.12 & 1.22 \\
$\mathrm{~A} \beta 1-40$ & 4330.87 & 4331.28 & 0.41 \\
$\mathrm{~A} \beta 1-42$ & 4515.10 & 4515.90 & 0.80 \\
\hline
\end{tabular}

Table 6. Correlations between A $\beta$ levels and synaptophysin levels in human brain homogenates.

\begin{tabular}{|c|c|c|c|c|c|c|c|c|c|c|c|c|c|c|}
\hline & & \multicolumn{2}{|c|}{ Western blot } & \multicolumn{4}{|c|}{ XMAP } & \multicolumn{7}{|c|}{ SELDI-TOF MS } \\
\hline & & A $\beta_{\text {MONOMER }}$ & $\mathbf{A} \boldsymbol{\beta}_{\text {DIMER }}$ & $\begin{array}{c}\mathbf{A} \boldsymbol{\beta}_{1-} \\
40 \\
\end{array}$ & $\mathbf{A} \boldsymbol{\beta}_{\mathrm{n}-40}$ & $\mathbf{A} \boldsymbol{\beta}_{1-42}$ & $\begin{array}{c}\mathbf{A} \boldsymbol{\beta}_{\mathrm{n}-} \\
42\end{array}$ & $\mathbf{A} \boldsymbol{\beta}_{5-42}$ & $\mathbf{A} \boldsymbol{\beta}_{4-42}$ & $\begin{array}{c}{ }_{\mathrm{pE}} \mathbf{A} \boldsymbol{\beta}_{3-} \\
{ }_{42} \\
\end{array}$ & $\mathbf{A} \boldsymbol{\beta}_{3-42}$ & $\mathbf{A} \boldsymbol{\beta}_{2-42}$ & $\mathbf{A} \boldsymbol{\beta}_{1-42}$ & $\mathbf{A} \boldsymbol{\beta}_{\text {SUM }}$ \\
\hline \multirow[t]{2}{*}{ Synaptophysin } & $\mathbf{r}_{\text {PEARSON }}$ & -0.46 & -0.51 & -0.59 & -0.62 & -0.22 & -0.41 & -0.23 & -0.17 & -0.34 & -0.54 & -0.26 & -0.08 & -0.41 \\
\hline & p-value & 0.0168 & 0.0083 & 0.002 & 0.0007 & 0.284 & 0.038 & 0.2671 & 0.4112 & 0.0884 & 0.004 & 0.1986 & 0.6844 & 0.0358 \\
\hline
\end{tabular}


Table 7. Correlations of A $\beta$ levels across the techniques. Pearson's $r$ are presented in the top right p-values are presented in italics in the bottom left.

\begin{tabular}{|c|c|c|c|c|c|c|c|c|c|c|c|c|c|}
\hline & & \multirow{2}{*}{$\begin{array}{c}\text { Western } \\
\text { blot }\end{array}$} & \multicolumn{4}{|c|}{ xMAP } & \multicolumn{7}{|c|}{ SELDI-TOF MS } \\
\hline & & & $\mathrm{A} \beta_{1-40}$ & $\mathrm{~A} \beta_{\mathrm{n}-40}$ & $\mathrm{~A} \beta_{1-42}$ & $\mathrm{~A} \beta_{\mathrm{n}-42}$ & $A \beta_{5-42}$ & $\mathrm{~A} \beta_{4-42}$ & ${ }_{\mathrm{pE}} \mathrm{A} \beta_{3-42}$ & $A \beta_{3-42}$ & $\mathrm{~A} \beta_{2-42}$ & $\mathrm{~A} \beta_{1-42}$ & $\mathrm{~A} \beta_{\mathrm{SUM}}$ \\
\hline $\begin{array}{l}\text { Western } \\
\text { blot }\end{array}$ & MONOMER & - & 0.734 & 0.575 & 0.315 & 0.436 & 0.273 & 0.369 & 0.525 & 0.762 & 0.499 & 0.338 & 0.486 \\
\hline \multirow[t]{3}{*}{ xMAP } & $\mathrm{A} \beta_{1-40}$ & 0.000 & - & 0.885 & 0.205 & 0.287 & -0.079 & -0.014 & 0.198 & 0.740 & 0.126 & -0.005 & 0.129 \\
\hline & $\mathrm{A} \beta_{\mathrm{n}-40}$ & 0.001 & 0.000 & - & 0.406 & 0.502 & -0.024 & 0.022 & 0.260 & 0.646 & 0.150 & 0.003 & 0.142 \\
\hline & $\mathrm{A} \beta_{1-42}$ & 0.090 & 0.278 & 0.026 & - & 0.853 & 0.369 & 0.382 & 0.521 & 0.217 & 0.600 & 0.601 & 0.529 \\
\hline \multirow{8}{*}{$\begin{array}{l}\text { SELDI- } \\
\text { TOF MS }\end{array}$} & $\mathrm{A} \beta_{\mathrm{n}-42}$ & 0.016 & 0.124 & 0.005 & 0.000 & - & 0.549 & 0.553 & 0.670 & 0.355 & 0.639 & 0.554 & 0.620 \\
\hline & $A \beta_{5-42}$ & 0.144 & 0.680 & 0.902 & 0.045 & 0.002 & - & 0.933 & 0.822 & 0.323 & 0.778 & 0.722 & 0.869 \\
\hline & $\mathrm{A} \beta_{4-42}$ & 0.044 & 0.941 & 0.910 & 0.037 & 0.002 & 0.000 & - & 0.821 & 0.431 & 0.794 & 0.747 & 0.914 \\
\hline & ${ }_{\mathrm{pE}} \mathrm{A} \beta_{3-42}$ & 0.003 & 0.294 & 0.165 & 0.003 & 0.000 & 0.000 & 0.000 & - & 0.612 & 0.943 & 0.829 & 0.936 \\
\hline & $\mathrm{A} \beta_{3-42}$ & 0.000 & 0.000 & 0.000 & 0.249 & 0.054 & 0.082 & 0.017 & 0.000 & - & 0.535 & 0.404 & 0.585 \\
\hline & $\mathrm{A} \beta_{2-42}$ & 0.005 & 0.506 & 0.429 & 0.000 & 0.000 & 0.000 & 0.000 & 0.000 & 0.002 & - & 0.952 & 0.960 \\
\hline & $\mathrm{A} \beta_{1-42}$ & 0.068 & 0.980 & 0.986 & 0.000 & 0.001 & 0.000 & 0.000 & 0.000 & 0.027 & 0.000 & - & 0.925 \\
\hline & $\mathrm{A} \beta_{\mathrm{SUM}}$ & 0.006 & 0.498 & 0.454 & 0.003 & 0.000 & 0.000 & 0.000 & 0.000 & 0.001 & 0.000 & 0.000 & - \\
\hline
\end{tabular}




\section{Figures}

Fig. 1 WO2 western blot analysis of human brain homogenates. a Representative western blot showing bands consistent with 'monomeric' and 'dimeric' $\mathrm{A} \beta$. Densitometric analysis of the b 'monomeric' $A \beta$ and $\mathbf{c}$ 'dimeric' $A \beta$ bands in conjunction with ANOVA revealed that both 'monomeric' and 'dimeric' bands were significantly elevated within the AD tissue. $\beta$ tubulin loading control was used to normalize data. d Pearson's correlation revealed a significant positive correlation between the 'monomeric' and 'dimeric' $\mathrm{A} \beta$ bands visualized by the WO2 western blots. The $\triangle \mathrm{E} 9 \mathrm{fAD}$ case was shown to be an outlier and was removed from this analysis so as not to drive the positive correlation.

Fig. 2 a Representative WO2 SELDI-TOF MS spectra of AD, FTLD and neurologically normal cortical tissue. b Spectra arising from the AD tissue displayed an array of $\mathrm{N}$ terminally truncated $A \beta$ species of which $A \beta_{4-42}$ and $A \beta_{1-42}$ were the predominant species. Data represents average peak intensity of $A \beta$ species observed within $A D$ tissue. $\mathbf{c}$ The peak observable at $4329 \mathrm{Da}$ could have been attributed to either $\mathrm{A} \beta_{3-42}(4329 \mathrm{Da})$ or $A \beta_{1-40}(4330$ Da). However analysis of the $\mathrm{AD}$ homogenate with $\mathrm{G} 210$, an $\mathrm{A} \beta_{40}$ specific antibody, showed no peaks consistent with $A \beta_{n-40}$ species unless the homogenate was spiked with synthetic $A \beta_{1-}$ 40 prior to analysis. Low levels of $A \beta_{1-42}$ likely resulting from non-specific binding with $\mathrm{G} 210$ were observable in the $\mathrm{AD}$ tissue

Fig. 3 Comparative analysis of the $A \beta$ species observed within the WO2 SELDI-TOF MS spectra revealed that whilst no significant difference was found across the diagnostic groups with regard to $\mathbf{a} A \beta_{5-42}$, significant differences were observed for peaks corresponding to $\mathbf{b}$ $\mathrm{A} \beta_{4-42}(\mathrm{p}=0.0313), \mathbf{c} \mathrm{pEA} \beta_{3-42}(\mathrm{p}=0.0154), \mathbf{d} \mathrm{A} \beta_{3-42}(\mathrm{p}=0.0090), \mathbf{e} \mathrm{A} \beta_{2-42}(\mathrm{p}=0.0014)$, and f $A \beta_{1-42}(\mathrm{p}=0.0028)$. Post-hoc analyses indicated that there were significantly higher levels 
of $\mathrm{pEA} \beta_{3-42}$ and $A \beta_{3-42}$ in the $\mathrm{AD}$ brain homogenate compared with control tissue and significantly higher $\mathrm{A} \beta_{2-42}$ and $\mathrm{A} \beta_{1-42}$ in the $\mathrm{AD}$ tissue compared to both FTLD and control homogenates

Fig. 4 a Representative WO2 western blots of the three familial AD cases showed that there were elevated levels of observable A $\beta$ / APP fragments within the $\Delta \mathrm{E} 9$ tissue compared to the two PS1 mutations. b Representative WO2 SELDI-TOF MS spectra showed that the PS1 mutations resulted in $A \beta$ profiles indistinguishable from those observed in the sporadic $A D$ tissue. The $\mathrm{A} \beta$ profile arising from the $\Delta \mathrm{E} 9$ tissue however, showed a distinct pattern of $\mathrm{N}$ terminally truncated $A \beta_{n-40}$ species alongside $A \beta 1-38, p E A \beta_{3-42}$ and $A \beta_{1-42}$. The peak visible before $\mathrm{pEA} \beta_{3-42}$ in the $\mathrm{C} 263 \mathrm{~T}$ spectra (4270 Da) did not match any known $\mathrm{A} \beta$ species. c These N-terminal species were also readily observable when analysed with the $A \beta_{40}$ specific antibody G2-10

Fig. 5 a Representative western blot analysis of synaptophysin levels within the AD and control tissue. $\beta$-tubulin loading control was used to normalize data. b Densitometric analysis in conjunction with one-way ANOVA indicated that brain homogenates affected by $\mathrm{AD}$, FTLD and FAD all had significantly lower levels of synaptophysin than the control tissue $(\mathrm{p}<0.0001)$

Fig. 6 a Representative WO2 SELDI-TOF MS spectra of AD and control tissue demonstrated that whilst monomeric $A \beta$ species were readily observable, peaks consistent with dimeric $A \beta$ were not seen within the spectra. b Analysis of AD homogenate spiked with $100 \mathrm{fM}$ of dityrosine cross-linked $\mathrm{A} \beta_{1-40} \mathrm{Met}_{35}(\mathrm{O})$ demonstrated that the SELDI-TOF MS methodology was capable of observing dimeric $A \beta$ at low concentrations. c WO2 western blot of 
increasing concentrations of synthetic di-tyrosine cross-linked $A \beta_{1-40} \operatorname{Met}_{35}(\mathrm{O})$ : (A) $100 \mathrm{fM}$, (B) $100 \mathrm{pM}$, (C) $100 \mathrm{nM}$, (D) $500 \mathrm{nM}$, (E) $1 \mu \mathrm{M}$, (F) $5 \mu \mathrm{M}$, and (G) $10 \mu \mathrm{M}$

Fig. 7 a WO2 western blots of an AD brain homogenate prepared in sample buffer, with concentrations of SDS ranging from $0.5 \%$ to four percent. a Densitometric analysis of the blots showed that there was a significant difference in the levels of observable 'dimeric' $\mathrm{A} \beta$ across the groups $(\mathrm{p}=0.0462)(\mathrm{n}=3)$. $\mathbf{c}$ WO2 western blots of synthetic $\mathrm{A} \beta_{1-42}$ prepared in sample buffer with concentrations of SDS ranging from $0.5 \%$ to four percent. d Densitometric analysis of the blots showed that there was a significant increase in the 'dimeric' $A \beta$ bands observed as the concentration of SDS in the sample buffer was increased $(\mathrm{p}<0.0001)(\mathrm{n}=4)$. Data normalized to normal $(2 \%)$ SDS concentration 
Fig. 1

a

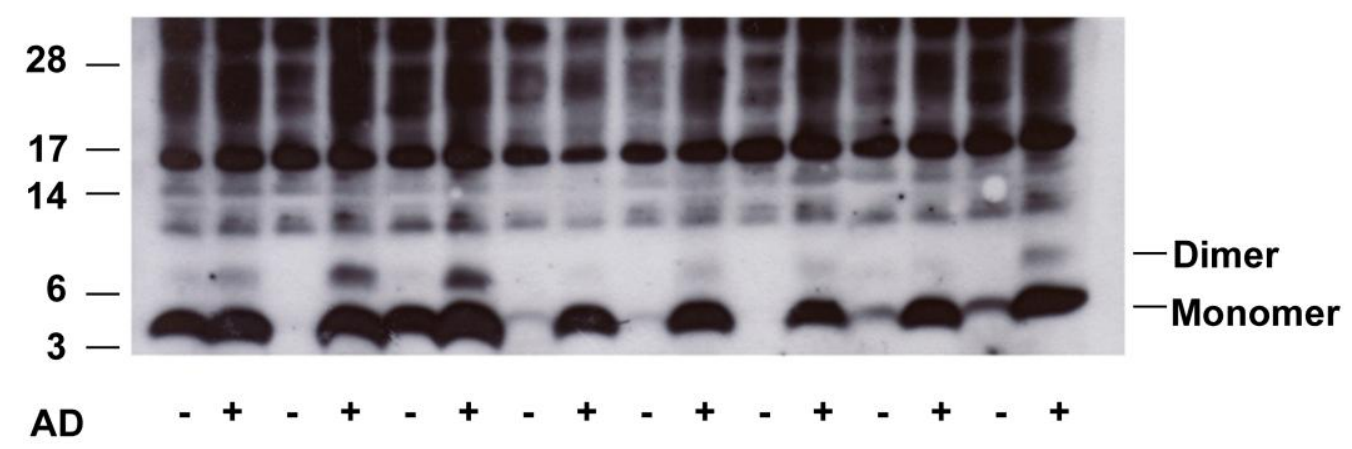

$\beta$-Tubulin

b

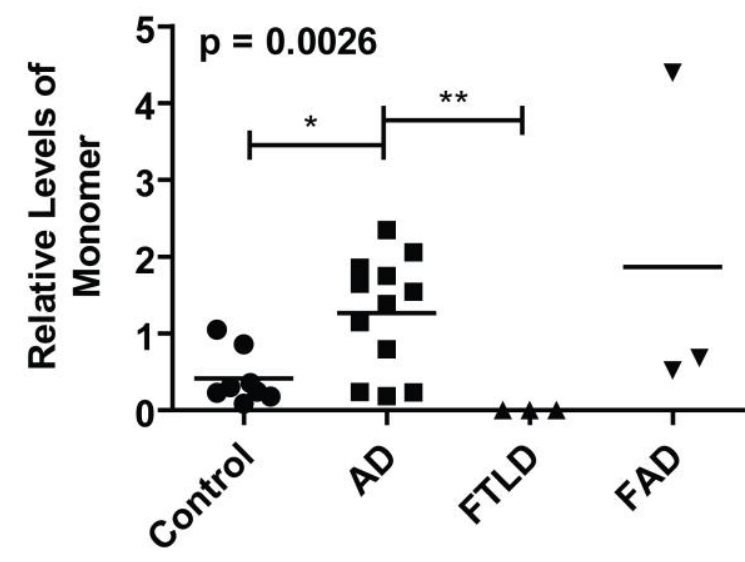

d

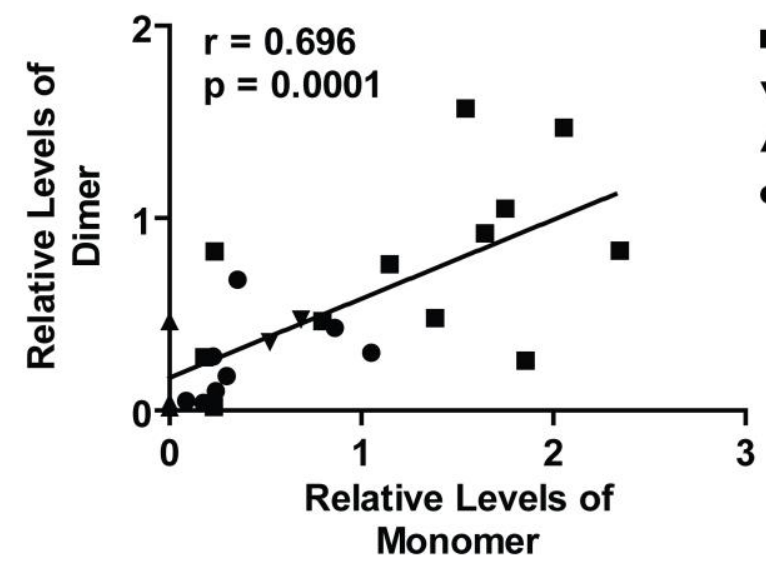

C

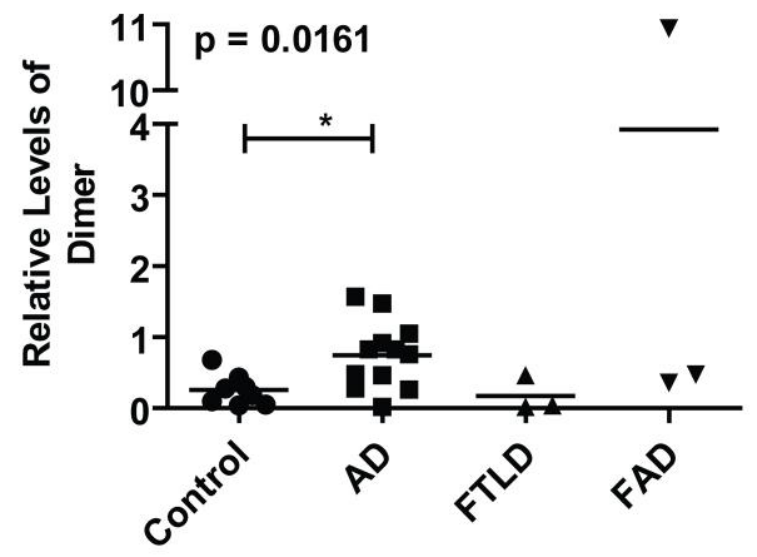

- $A D$

- FAD

- FTLD

- Control 
Fig. 2

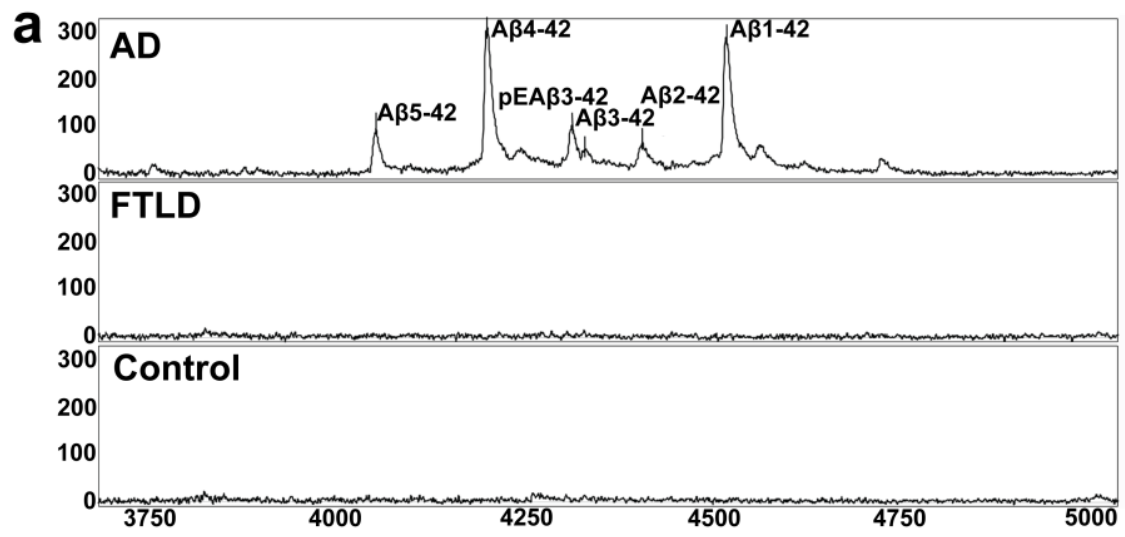

b
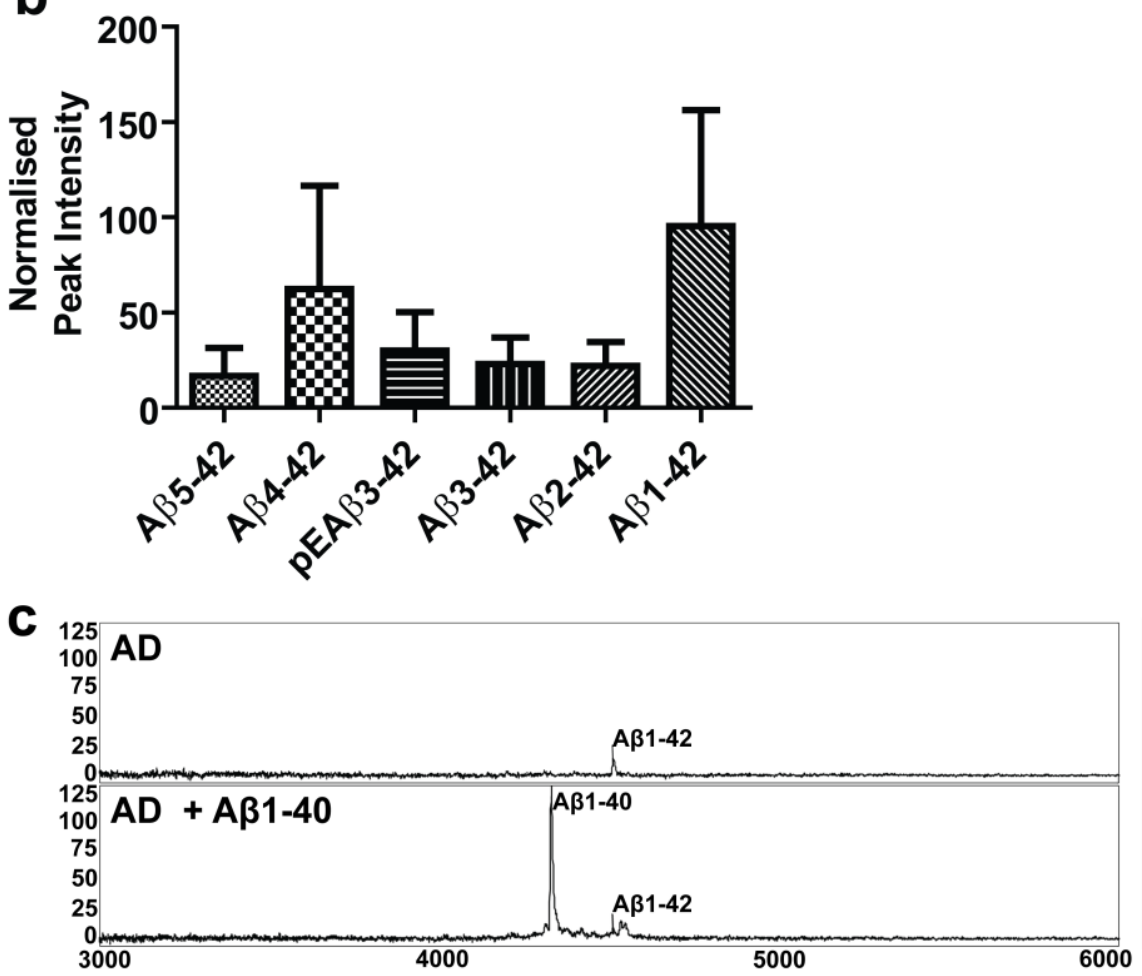
Fig. 3

a

Aß5-42

b A 44-42
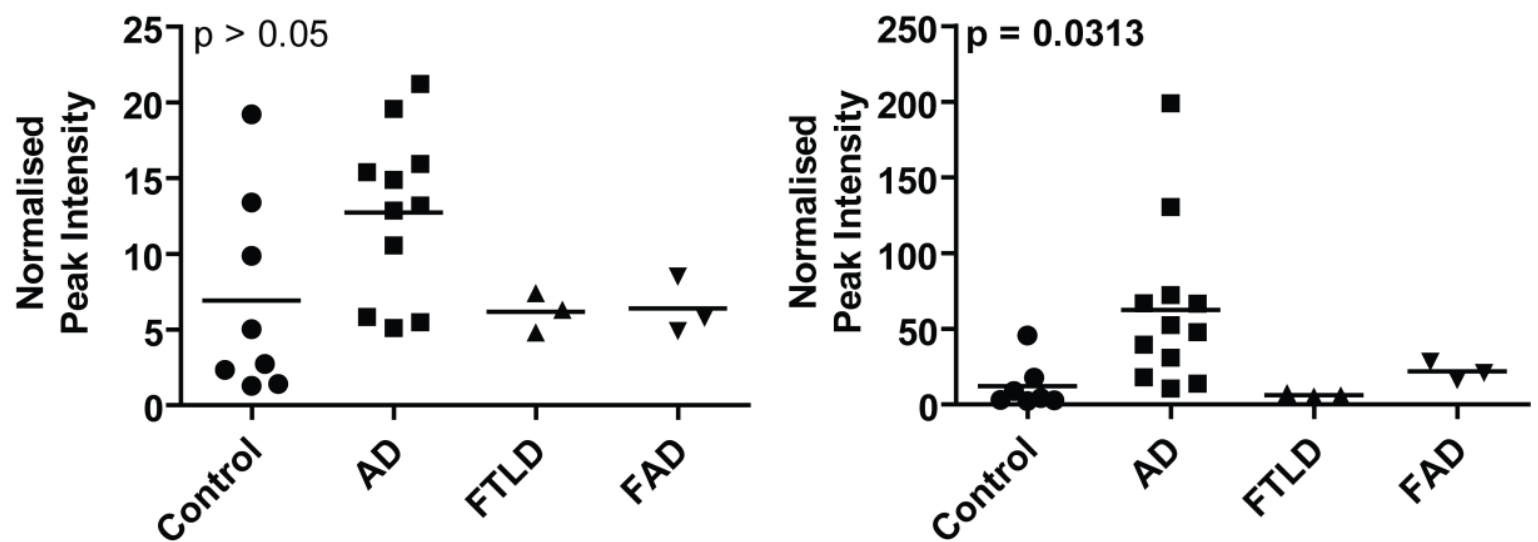

C

Aß3-42

d

pEAß3-42
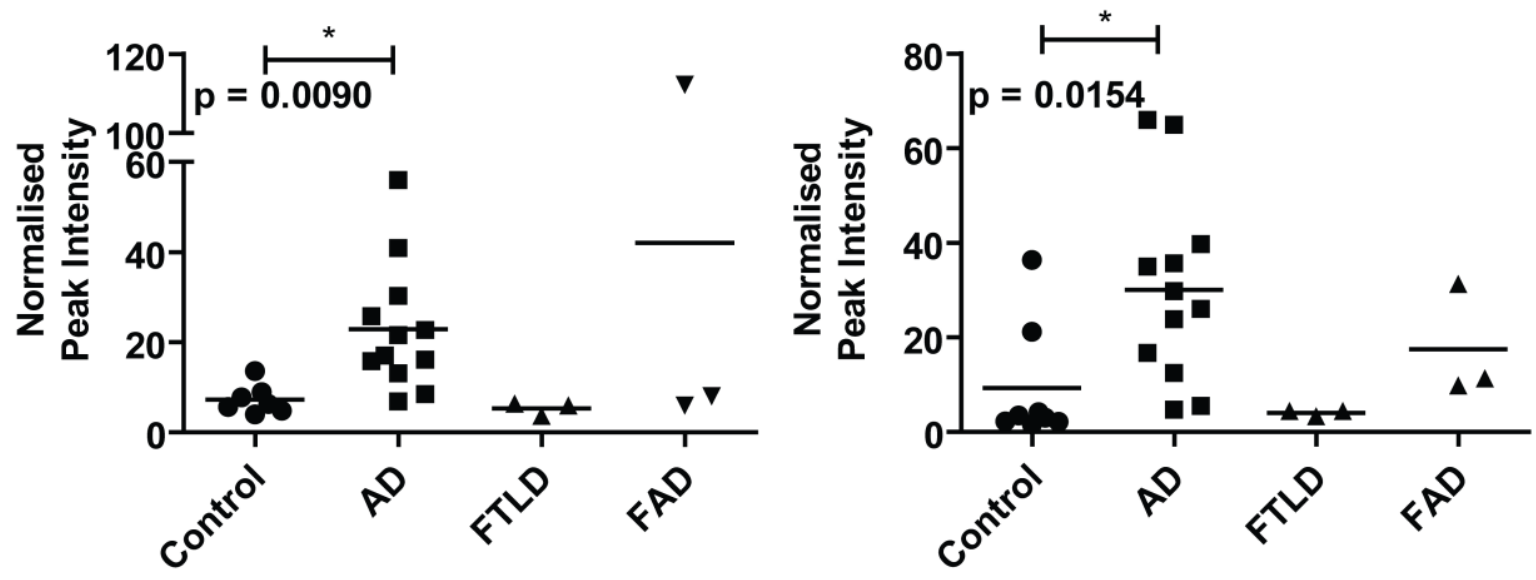

e

A $32-42$

f
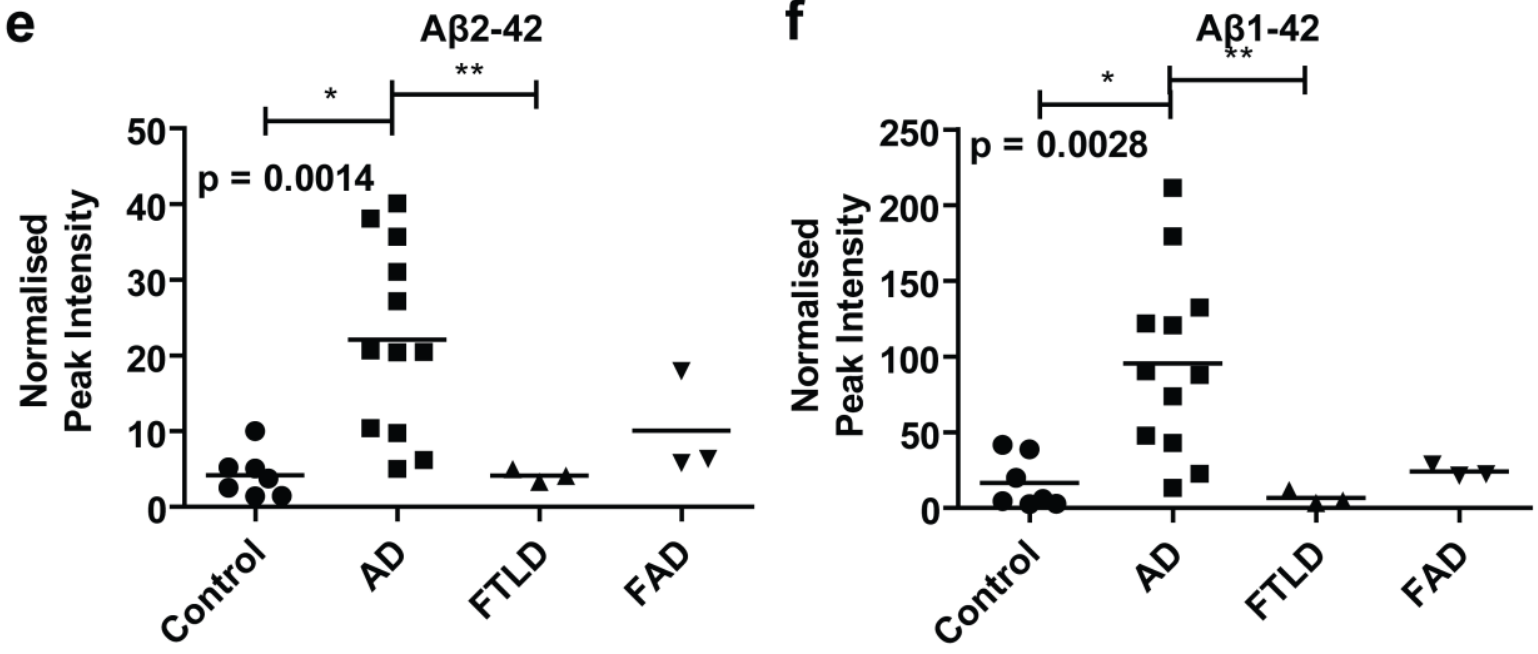
Fig. 4
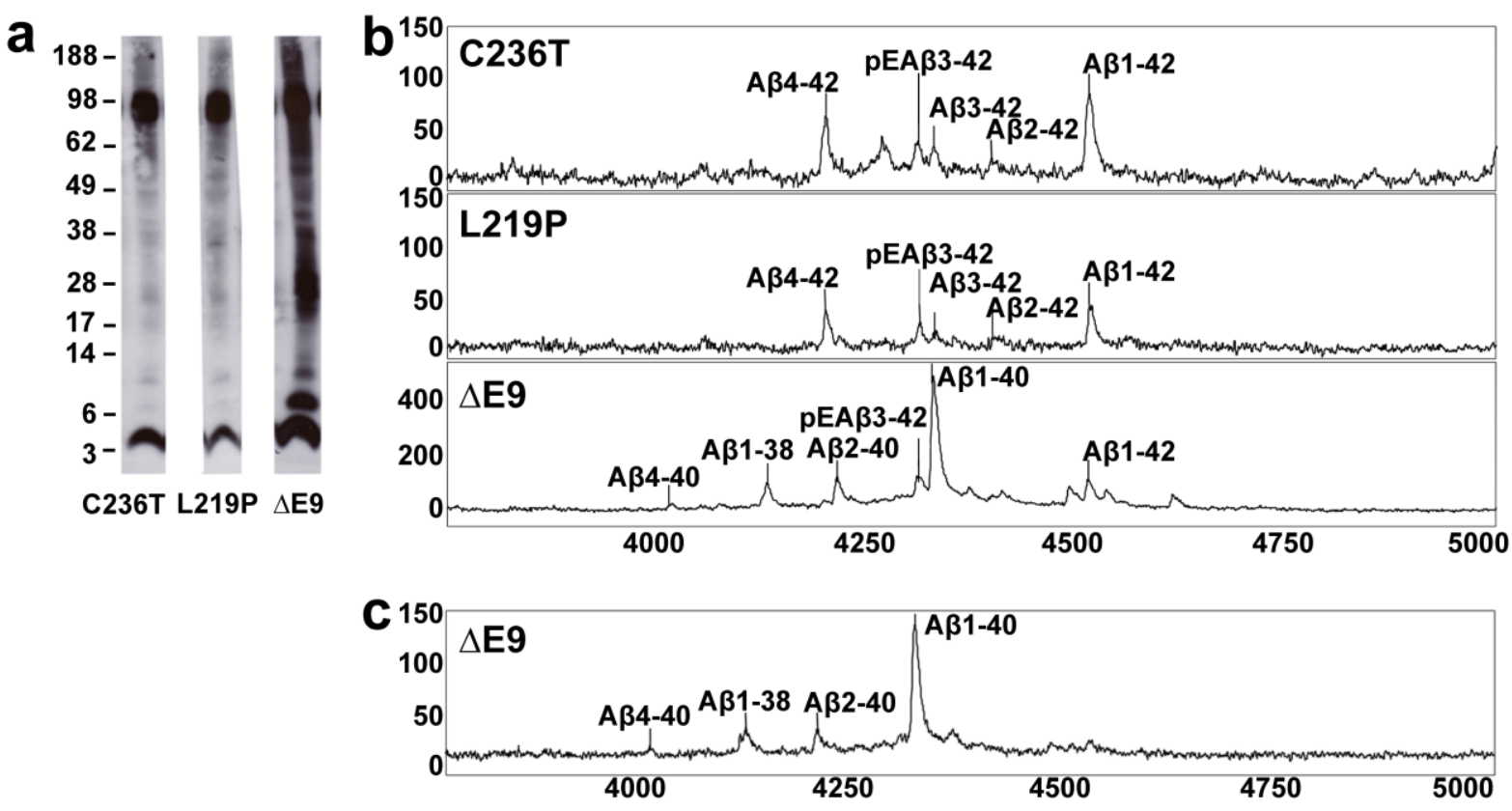
Fig. 5

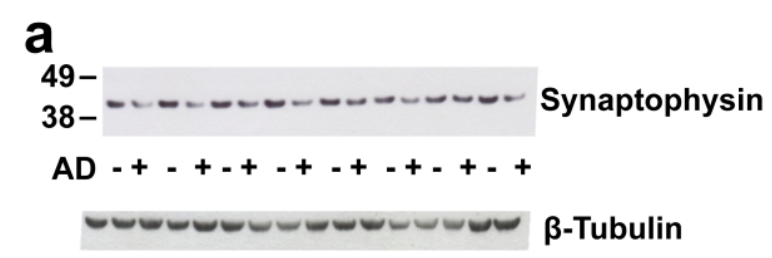

b
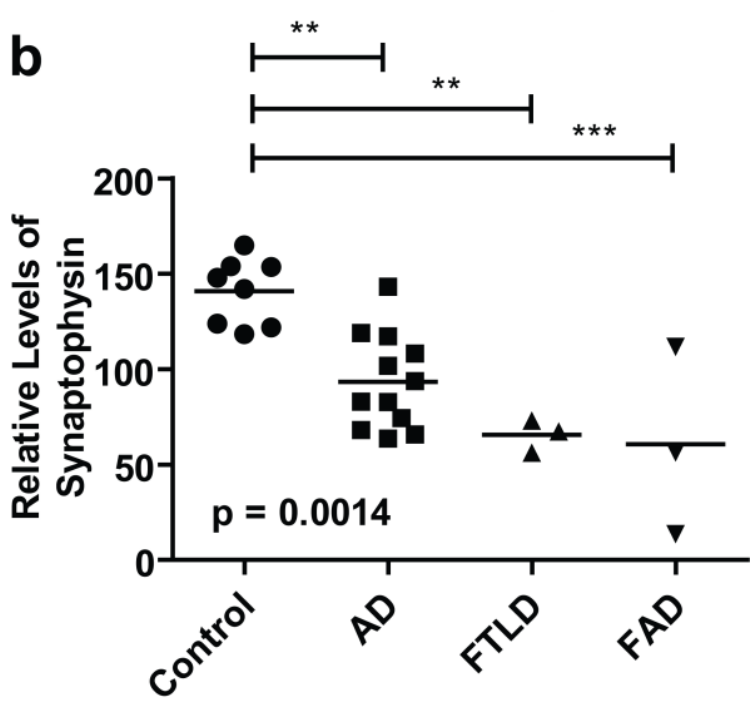

43 
Fig. 6

\section{a}

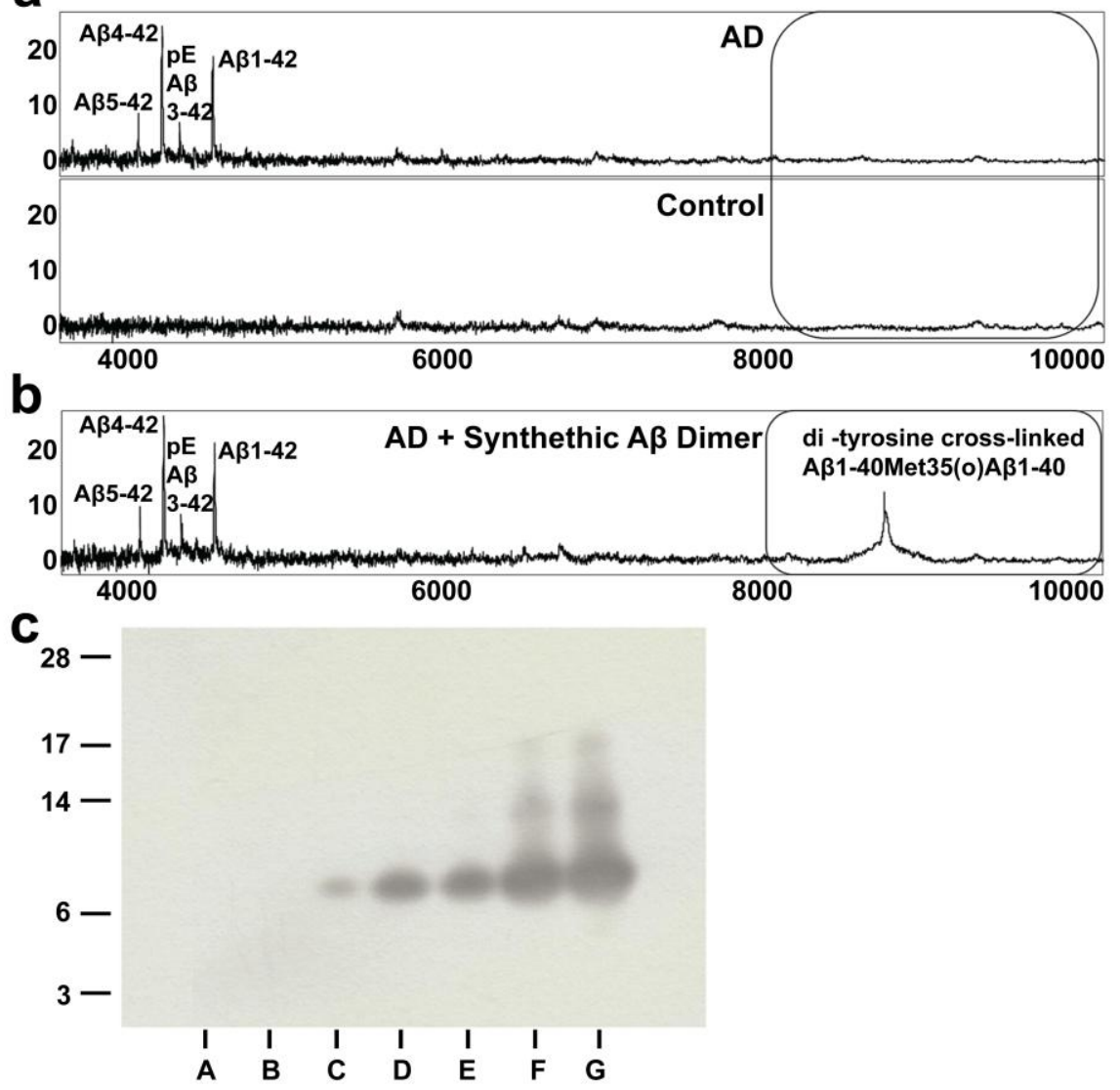


Fig. 7

a

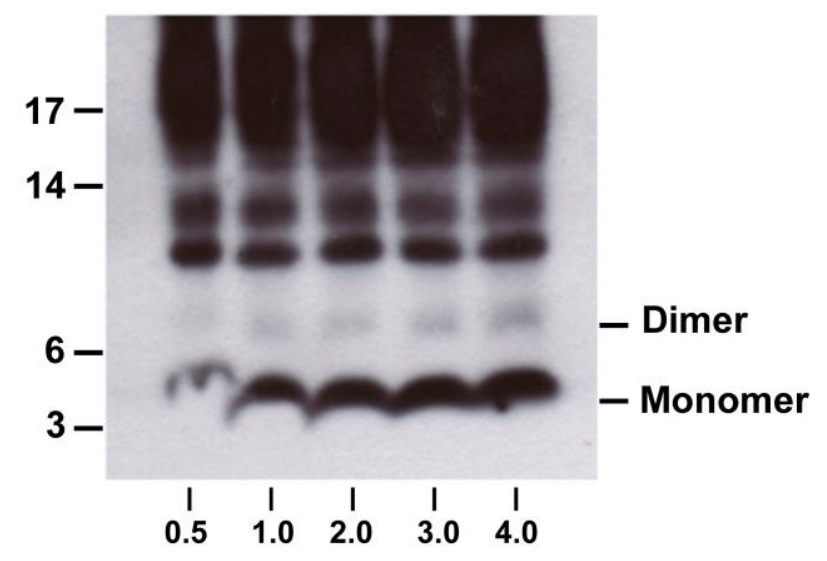

SDS Concentration (\%)

C

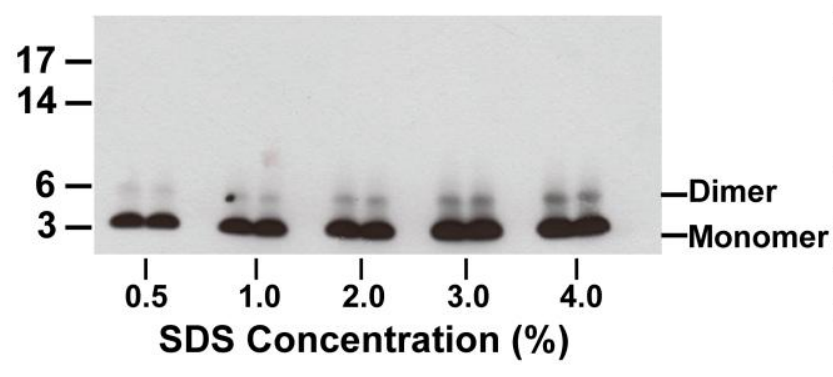

b

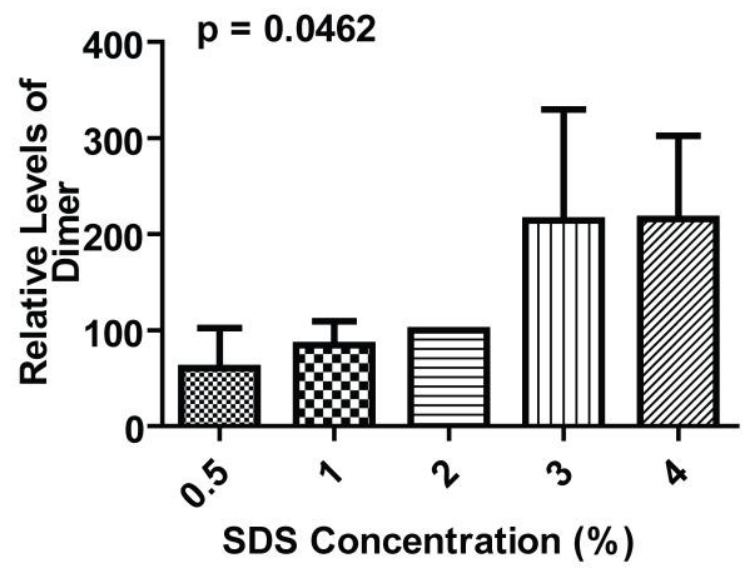

d
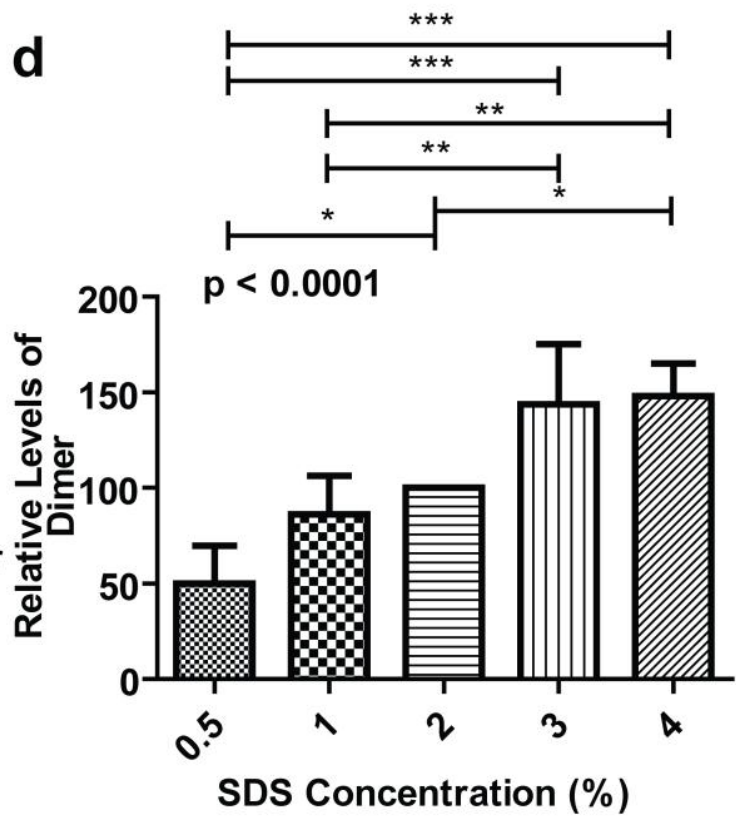


\section{Supplementary Figures}

Fig. 1 Densitometric analysis of the blots showed that there was no difference in monomeric $A \beta$ levels as the concentration of SDS in the sample buffer was increased $(p>0.05)(n=4)$.

Data normalized to normal (2\%) SDS concentration

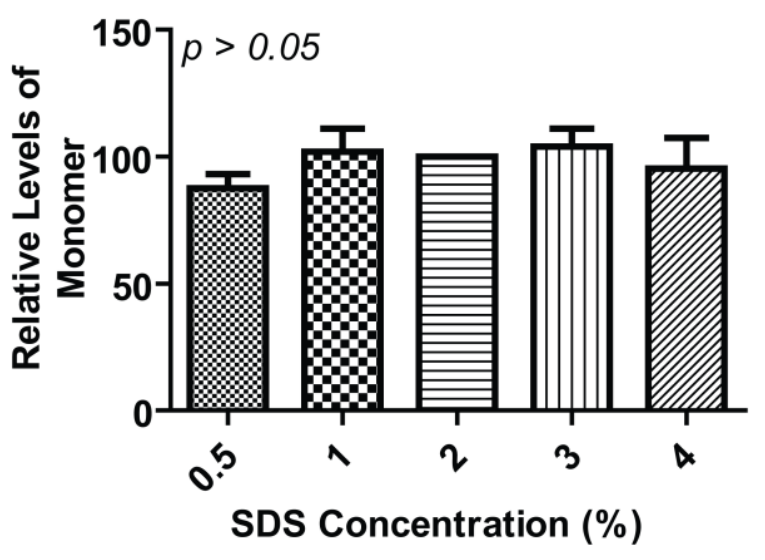




\section{University Library}

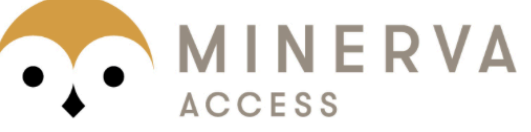

A gateway to Melbourne's research publications

Minerva Access is the Institutional Repository of The University of Melbourne

\section{Author/s:}

Watt, AD;Perez, KA;Rembach, A;Sherrat, NA;Hung, LW;Johanssen, T;McLean, CA;Kok, WM;Hutton, CA;Fodero-Tavoletti, M;Masters, CL;Villemagne, VL;Barnham, KJ

Title:

Oligomers, fact or artefact? SDS-PAGE induces dimerization of beta-amyloid in human brain samples

Date:

2013-04-01

Citation:

Watt, A. D., Perez, K. A., Rembach, A., Sherrat, N. A., Hung, L. W., Johanssen, T., McLean, C. A., Kok, W. M., Hutton, C. A., Fodero-Tavoletti, M., Masters, C. L., Villemagne, V. L. \& Barnham, K. J. (2013). Oligomers, fact or artefact? SDS-PAGE induces dimerization of beta-amyloid in human brain samples. ACTA NEUROPATHOLOGICA, 125 (4), pp.549-564. https://doi.org/10.1007/s00401-013-1083-z.

Persistent Link:

http://hdl.handle.net/11343/59341 